\title{
«THE COMING SHADOW OF A MIGHTY WAR.» LES \\ REVUES DANS LA BATAILLE ANGLO-AMERICAINE SUR LA CODIFICATION DU COMMON LAW (1820-1835) \\ «THE COMING SHADOW OF A MIGHTY WAR.» LAS REVISTAS EN LA BATALLA ANGLO-AMERICANA SOBRE LA CODIFICACIÓN DEL COMMON LAW (1820- 1835)

\author{
«THE COMING SHADOW OF A MIGHTY WAR.» THE \\ REVIEWS IN ANGLO-AMERICAN BATTLE ABOUT \\ CODIFICATION OF THE COMMON LAW (1820-1835)
}

\author{
SYLVAIN SOLEIL ${ }^{1}$
}

Recibido: $21 / 04 / 2020$

Aceptado: 08/06/2020

SOMMAIRE: I. L’art de la controverse dans les revues. 1. Les supports: journaux, revues littéraires et revues juridiques. 2. L’outil: la recension. 3. Les usages: les arguments, la modération, la loyauté. 4. L'hystérie: l'exemple de l'essay on the doctrine of contracts de verplanck. II. Le choc des lignes editoriales. L'exemple de the jurist v. The law magazine. 1. Les idées directrices respectives. 2. L'affaire des pays-bas. 3. Le choix des recensions et des informations. III. Conclusions.

SUMARIO: I. El arte de la controversia en las revistas. 1. Los soportes: periódicos, revistas literarias y revistas jurídicas. 2. El instrumento: la recensión. 3. Los usos: los argumentos, la moderación, la lealtad. 4. La histeria: el ejemplo del ensayo sobre la doctrina de los contratos de verplanck. II. El choque de las líneas editoriales. El ejemplo de the jurist v. The law magazine. 1. Las ideas directrices respectivas. 2. El caso de los países bajos. 3. La elección de las recensiones e informaciones. III. Conclusiones.

SUMMARY. I. The art of controversy in journals. 1. The media: newspapers, literary and legal journals. 2. The tool: the review. 3. Uses: arguments, moderation, loyalty. 4. Hysteria: the example of verplanck's essay on the doctrine of contracts. II. The clash of editorial lines. The example of the jurist v. The law magazine. 1. The respective guiding ideas. 2. The netherlands case. 3. The choice of reviews and information. III. Conclusions.

RESUME. Durant les années 1820-1835, le monde des juristes anglo-américains s'est embrasé. En lien avec les chantiers de réforme au Royaume-Uni, en Louisiane, en Caroline du Sud ou dans l'Etat de New-York, il s'agit de savoir s'il serait opportun d'abolir le common law afin de lui substituer des codes. A l'origine, les deux controverses anglo-américaines étaient indépendantes l'une de l'autre, mais, très vite, elles vont s'entremêler notamment parce que les revues vont devenir un lieu d'affrontement transatlantique. Il s'agit d'un phénomène éditorial que l'on peut analyser en examinant la façon dont s'organise l'art de la controverse dans les revues littéraires ou juridiques, puis en suivant la lutte particulière que se livrent deux revues

\footnotetext{
${ }^{1}$ Catedrático de Historia del Derecho de la Universidad de Rennes 1 -Francia-. IODE (UMR CNRS 6262).sylvain.soleil@univ-rennes1.fr
} 
britanniques fondées respectivement en 1827 et en 1828, l'une pour prendre la défense du common law, l'autre pour écraser les velléités codificatrices.

MOTS-CLÉ. Common Law - Civil Law - Codification - revues juridiques - Jeremy Bentham - Carl von Savigny - William Sampson - Peter S. Du Ponceau - James Humphreys - Gulian C. Verplanck - John Reddie - John J. Park - Charles P. Cooper Sutton Sharpe - Abraham Hayward

RESUMEN: Durante los años 1820-1835, el mundo de los juristas anglo-americanos había estallado. Ligado a los cantos de reforma en el Reino Unido, en Luisiana, en Carolina del Sur o en los Estados de Nueva York, trataban de saber si era oportuno abolir el common law con el fin de sustituirlo por los códigos. Desde un principio, las dos controversias anglo-americanas eran independientes la una de la otra, pero, rápidamente, ambas se entrelazarán particularmente debido a que las revistas se van a convertir en un lugar de confrontación trasatlántica. Se trata, en suma, de un fenómeno editorial que podemos analizar examinando la forma de cómo se organiza el arte de la controversia en las revistas británicas creadas respectivamente en 1827 y 1828, una para posicionarse en defensa del common law, la otra para desacreditar las veleidades de la codificación.

PALABRAS CLAVE. Common Law - Civil Law - Codificación - revistas juridicas Jeremy Bentham - Carl von Savigny - William Sampson - Peter S. Du Ponceau - James Humphreys - Gulian C. Verplanck - John Reddie - John J. Park - Charles P. Cooper Sutton Sharpe - Abraham Hayward

ABSTRACT: During the period 1820-1835, the Anglo-American legal world was set ablaze. Like the reforms taking place in the United Kingdom, Louisiana, South Carolina and New York State, this was about finding the right moment to abolish common law and replace it with codes. Although the two Anglo-American controversies were originally independent of each other, they very soon became intertwined, in particular because the reviews were the cause of a transatlantic confrontation. This was an editorial phenomenon that can be analysed by examining the way in which the art of controversy is organised in the literary and legal reviews, then by following the particular battle between two British reviews founded in 1827 and 1828 respectively, one in defence of common law, the other to eliminate the vague hopes of codification.

KEY WORDS. Common Law - Civil Law - Codification - legal journals - Jeremy Bentham - Carl von Savigny - William Sampson - Peter S. Du Ponceau - James Humphreys - Gulian C. Verplanck - John Reddie - John J. Park - Charles P. Cooper Sutton Sharpe - Abraham Hayward 
En janvier 1827, William H. Gardiner, un juriste américain du Massachussetts, met en garde ses lecteurs devant la guerre qui se profile... Dans The North American Review, il en résume l'enjeu: «Il y a peu de questions de progrès interne sur lesquels les esprits libres et énergiques sont plus divisés que celle de l'intérêt et de la possibilité de substituer un code général pour la masse entière du common et du statute law.» Gardiner explique avoir cherché l'argumentation des deux côtés. «Il n’y a pas grand mal à cela, admet-il, tant que nous ne nous drapons pas dans un caractère d'individualité inflexible». Mais, ajoute-t-il, lorsqu'on fait le lien entre ces diverses opinions et ce qui se passe désormais en Louisiane où le nouveau code, quoique promulgué, est attaqué et défendu avec une ardeur proche de l'amertume ${ }^{2}$ :

«S’il nous est permis d'user un peu de l'esprit de prophétie, nous pensons pouvoir percevoir en cela l'ombre croissante d'une formidable guerre. [...] Les codes doivent être proposés, discutés, assaillis, défendus, dans toute l'Union: et nous attendons le jour où les codificateurs et les anticodificateurs mèneront une guerre aussi féroce et interminable que celle qui a fait rage autrefois entre les docteurs de l'Amirauté et les serviteurs de Sa Majesté du Banc du Roi.»

De quoi s’agit-il? En 1824, aux Etats-Unis, en 1826, au Royaume-Uni, le monde des juristes s'est embrasé autour de la même question: est-il opportun d'abolir le common law au profit d'un code? A l'origine, les deux controverses anglo-américaines sont indépendantes l'une de l'autre. Aux Etats-Unis, cela fait une trentaine d'années que, dans les divers Etats de l'Union, plusieurs réseaux de juristes se lamentent devant les incertitudes et les mystères du common law (les règles de justice que les juges matérialisent à l'occasion de leurs décisions), devant la masse confuse et croissante des statuts (les lois des assemblées législatives), et - pour les plus radicaux - devant le caractère non-américain et non-républicain du droit dont ils ont hérité des Anglais lors de l'indépendance $(1776)^{3}$. C'est William Sampson, un avocat d'origine irlandaise, qui déclenche la controverse en décembre 1823, à l'occasion d'un discours prononcé à New-York dans lequel il met longuement en accusation le common law afin de justifier la mise au point d'un code, à l'exemple de la Louisiane ${ }^{4}$. Dans ce territoire acquis par les Etats-Unis en 1803, un code civil (sur le modèle du code Napoléon), un code de

\footnotetext{
${ }^{2}$ «If we may be allowed to exercise a little of the spirit of prophecy, we think we can perceive in this the coming shadow of a mighty war [...] Codes are to be proposed, discussed, assailed, defended, throughout the union; and we look to see the day, when codifiers and anticodifiers will wage a war as fierce and interminable, as that which raged of yore between the Doctors of Admiralty and his Majesty's servants of King's Bench» (Gardiner, «Revision of the Laws of New York», The North American Review, 1827, vol. 24, p. 194).

3 William E. Nelson, Americanization of the Common Law: the Impact of Legal Change on Massachusetts Society, 1760-1830, Cambridge, Londres, Harvard University Press, 1975; F. Thornton Miller, Juries and judges versus the law: Virginia's provincial legal perspective, 1783-1828, Charlottesville, The University of Virginia Press, 1994; M. Grossberg et C. Tomlins (éd.), The Cambridge History of Law in America, Cambridge, Cambridge University Press, 2008, 3 vol., t. 1. Early America (1580-1815); L. Edwards, The People and their Peace: Legal Culture and the Transformation of Inequality in the Post-Revolutionary South, Chapel Hill, The University of North Carolina Press, 2009.

${ }^{4}$ P. Miller, «The common law and codification in Jacksonian America», Proceedings of the American Philosophical Society, 1959, p. 463 s.: M. Bloomfield, «William Sampson and the Codifiers: The Roots of American Legal Reform», The American Journal of Legal History, 1967, p. 234 s.: Charles M. Cook, The American Codification Movement: A Study of Antebellum Legal Reform, Westport, Greenwood Press, 1981: Robert W. Gordon, «The American Codification Movement», Faculty Scholarship Series, 1370, 1983, p. 439 s.: A. Mergey et S. Soleil, «Faut-il codifier le common law des Etats-Unis? La controverse Sampson v. Du Ponceau (1823-1826)», La controverse, Rennes, Presses Universitaires de Rennes, 2019, p. $149 \mathrm{~s}$.
} 
procédure et un code pénal sont à l'époque en préparation, sous la direction d'Edward Livingston, un juriste de New-York qui s'est converti au civil law ${ }^{5}$.

Au Royaume-Uni, cela fait également une trentaine d'années que des voix se font entendre, notamment dans les cercles benthamien et radicaux, pour réclamer la substitution d'un code au common law ${ }^{6}$. Bentham a inventé, à ce sujet, un substantif qui indique une procédure, une manière de faire: «codification» " ${ }^{7}$. Mais c'est James Humphreys, un attorney londonien, qui provoque les hostilités en publiant, en avril 1826, un projet de code sur la propriété réelle. Héritée du système féodal anglonormand, la propriété des biens réels, sa complexité, son vocabulaire et ses fictions font l'objet d'inquiétudes et de débats parmi les juristes depuis les années $1800^{8}$. Or, après avoir montré les défauts techniques du droit anglais, Humphreys propose, sur le modèle du code civil français, un projet de code original, réfléchi, détaillé, qui va déchainer les passions ${ }^{9}$.

Pour tous ces juristes anglo-américains, il ne s'agit pas d'une joute intellectuelle sans conséquence, car l'enjeu est aussi législatif: en Louisiane, en Caroline du Sud, dans l'Etat de New-York, des projets très avancés de codification sont en discussion dès le début des années 1820, tandis qu'au Royaume-Uni, la vie politique est rythmée par les travaux du comité de réforme animé par les leaders whigs (1819-1823), par les projets de lois de consolidation (1826-1830) défendus par Robert Peel, le Home Secretary des gouvernements conservateurs qui se succèdent jusqu'en 1830 et, après la défaite des tories aux élections de 1830, par les travaux des commissions de réforme mises en place par Brougham, le Lord Chancelor du gouvernement whig de Grey (1830-1834). A l'origine, les deux controverses anglo-américaines étaient indépendantes l'une de l'autre, mais, très vite, elles vont s'entremêler, non seulement parce que les ouvrages publiés de part et d'autre de l'Atlantique vont enrôler des auteurs, des ouvrages et des arguments venus de l'autre rive, mais encore et surtout

\footnotetext{
${ }^{5}$ Richard H. Kilbourne, A History of the Louisiana Civil Code: The Formative Years, 1803-1839, Baton Rouge, Louisiana State University Press, 1987: Vernon V. Palmer, «Two worlds in one: The genesis of Louisiana's mixed legal system, 1803-1812», Vernon V. Palmer (dir.), Louisiana: A Microcosm of a Mixed Jurisdiction, Durham, Carolina Academic Press, 1999, p. 23 et s.: A. Guzmán Brito, «Las fuentes de las normas sobre interpretación de la leyes del Digeste des lois civiles (Code civil) de la Luisiana (1808/1825)», Revista de estudios histórico-jurídicos, 2009, p. 171 et s.

${ }^{6}$ D. Liebermann, The Province of Legislation Determined: Legal Theory in Eighteenth Century Britain, Cambridge, Cambridge University Press, 1989; J. R. Dinwiddy, Radicalism and Reform in Britain, 17801850, Londres et Rio Grande, The Hambledon Press, 1992; R. Brown, Revolution, Radicalism and Reform. England 1780-1846, Cambridge, Cambridge University Press, 2000: G. Guyon, Les partisans de la codification en Angleterre. La question du droit pénal entre utilitarisme, modernisation du common law et modèle juridique français, Thèse, Droit, Université de Rennes 1, 2012.

7 J. Vanderlinden, «Code et codification dans la pensée de Jeremy Bentham», Tijdschrift voor Rechtsgeschidenis, 1964, p. 45 s.: Gerald J. Postema, Bentham and the Common Law Traditions, Oxford, Clarendon Press, 1989: D. Baranger, «Bentham et la codification», Droits. Revue française de théorie, de philosophie et de culture juridique, 1997, p. $17 \mathrm{~s}$.

${ }^{8}$ Andrew R. Buck, «Property, aristocracy and the reform of the land law in early Nineteenth-century England», The Journal of Legal History, 1995, p. 63 s.; John H. Johnson, «The reform of real property law in England», Columbia Law Review, 1925, p. 609 s.; E. Spring, «Landowners, Lawyers, and Land Law Reform in Nineteenth-century England», The American Journal of Legal History, 1977, p. 40 s.

${ }^{9}$ M. Lobban, The Common Law and English Jurisprudence, 1760-1850, Oxford, Clarendon Press, 1991; Gunter A. Weiss, "The enchantment of codification in the common law world », Yale Journal of International Law, 2000, p. 435 s.; S. Soleil, "In the Order of the Code Napoleon". Les carences du droit anglais au révélateur du modèle juridique français (1820-1840)», Aux confins du droit, hommage à Xavier Martin, Poitiers, Presses Universitaires de Poitiers - LGDJ, 2017, p. 377 s.
} 
parce que les revues vont devenir un lieu d'affrontement commun, partagé, transatlantique. C'est cette implication que nous nous proposons d'interroger. Comment le support éditorial des revues se prête-t-il au conflit? Par quel type d'informations et de recensions les protagonistes alimentent-ils la controverse? Comment et pourquoi la controverse suscite-elle la création de revues juridiques à propos de la question ellemême? Comment et pourquoi la controverse s'invite-t-elle dans les Quarterly, les revues littéraires trimestrielles, ce qui a pour effet de l'élargir au-delà du cercle des professions juridiques? Pour tirer les conséquences majeures de ce phénomène éditorial, il convient, d'une part, d'examiner la façon dont s'organise l'art de la controverse dans les revues littéraires ou juridiques, d'autre part, de suivre la lutte particulière que se livrent deux revues britanniques, l'une, The Jurist, fondée en 1827 pour encourager les réformes et les tentatives de codification, l'autre, The Law Magazine, fondée en 1828 pour prendre la défense du common law et écraser les velléités codificatrices.

\section{L'ART DE LA CONTROVERSE DANS LES REVUES}

\section{Les supports: journaux, revues littéraires et revues juridiques}

Tout est bon pour participer à la Codification Controversy. La presse quotidienne (ou hebdomadaire) en constitue l'une des tribunes car elle permet de mobiliser l'opinion publique dans des formats courts et incisifs. Aux Etats-Unis, c'est notamment le cas dans les territoires où les projets sont suffisamment avancés pour créer un clivage et dynamiser les prises de parole. En Caroline du Sud, la bataille s'invite dans les colonnes du Charleston Courier, du Columbian Telescope ou du Charleston Mercury ${ }^{10}$. A New-York, c'est dans The American, le National Advocate, l'Evening Post, le New York Paper ou le New York Daily Advertiser que l'on rend compte des débats qui accompagnent la préparation, le vote et la promulgation des nouveaux statuts consolidés ${ }^{11}$. A Londres, c'est dans le Morning Post, le Times ou le Morning Chronicle que l'on suit les débats de l'hiver 1827 sur les avant-projets de réforme. C'est dans le Morning Herald que Bentham, en mai 1828, offre l'un de ses pamphlets les plus durs à l'égard du common law ${ }^{12}$. Mais ce sont évidemment les revues littéraires et les revues juridiques qui permettent d'approfondir les argumentaires respectifs.

Les revues juridiques, pour leur part, offrent deux visages assez différents selon qu'elles se spécialisent dans l'édition de décisions de justice - ce sont les law reports, où il est peu ou pas question de la controverse - ou qu'elles s'ouvrent à des informations et des recensions d'ouvrages, et par conséquent à l'actualité des réformes ${ }^{13}$. Au Royaume-Uni, afin de marquer leur différence avec les law reports et de

\footnotetext{
10 «Sampson to Cooper», Thompson, Sampson's Discourse, and Correspondence with Various Learned Jurists, Upon the History of the Law, with the Addition of Several Essays, Tracts, and Documents, Relating to the Subject, Washington, 1826, p. 65; Charles M. Cook, The American Codification Movement..., op. cit., p. 125 s.

11 «Difficulties under the Revised Laws of New-York», New York Paper; «Codification», New York Daily Advertiser, cités par The United States Law Intelligencer and Review, 1830, vol. 2, p. 147-148 et 1831, vol. 3, p. 101; Charles M. Cook, The American Codification Movement..., op. cit., p. 131 s.

${ }^{12}$ G. Guyon, Les partisans de la codification..., op. cit., p. 168 et 132.

13 Sur les revues juridiques au Royaume-Uni, D. Ibbetson, «Legal periodicals in England 1820-1870», Zeitschrift für Neuere Rechtsgeschichte, 2006, p. 175 s.: R. Zimmerman, «Law journals in NineteenthCentury Scotland», 2008, p. 9 s. et S. Vogenauer, «Law journals in Nineteenth-Century England»,
} 
compenser le sentiment d'infériorité des juristes britanniques par rapport à la doctrine continentale, de nouvelles revues apparaissent, pour ou contre la codification, et se dotent de sous-titres qui annoncent clairement l'intention des directeurs: offrir de la jurisprudence, c'est-à-dire de la réflexion doctrinale. Ainsi The Jurist or Quarterly Journal of Jurisprudence and Legislation (1827), The Law Magazine or Quarterly Review of Jurisprudence (1828), The Legal Observer or Journal of Jurisprudence (1830). Aux Etats-Unis, The American Jurist and Law Magazine est fondé à Boston en 1829, à l'imitation de The [English] Jurist, afin, explique son fondateur, de produire des travaux juridiques de qualité. Elle est terminée, s'exclame-t-il, l'époque où les juristes américains devaient se contenter de lire les livres anglais, de suivre l'administration de la justice anglaise, de considérer les juristes anglais comme des maîtres. Ils ne seront bientôt que des collègues. Place, donc, à The American Jurist, qui examinera avec entrain les sujets de réforme. Or, ajoute l'auteur de l'Avertissement ${ }^{14}$ :

« Le sujet de la codification est un sujet qui s'inscrit très naturellement dans le programme de notre publication, et qui ne semble à sa place ni dans les journaux, ni dans les revues littéraires, bien qu'il l'ait occupée dans les uns et les autres, depuis que nous avons commencé à entendre parler de Jeremy Bentham.»

A l'inverse, The United States Law Intelligencer and Review (1829) réclame, selon son fondateur Joseph K. Angell, de la prudence et de l'intelligence lorsqu'il s'agit de confier à des juristes le soin de réviser, d'amender et de codifier les lois ${ }^{15}$.

Dans les faits, expliquent Michael L. Swygert et John W. Bruce, la plupart de ces nouvelles revues vont échouer à trouver leur public, parce que la réflexion doctrinale est encore très éloignée des préoccupations du bar et du bench (le barreau et la magistrature $)^{16}$. Sitôt créées, sitôt disparues... The United States Law Journal and Civilian's Magazine a vu le jour en 1822, grâce aux membres des barreaux de NewYork et du Connecticut, mais s'interrompt après le premier volume (1822-1823), avant de renaître en 1826 et de disparaître définitivement après le second volume. The United States Law Intelligencer and Review fait paraître trois volumes, de 1829 à 1831, puis met fin à la publication. Le Carolina Law Journal n'offre qu'un volume, en 1830. Même constat au Royaume-Uni. The Legal Observer or Journal of Jurisprudence, publié à Londres, Dublin et Edinburgh à compter de 1830, est fier d'expliquer que bien des revues antérieures ont été, «selon le mot d'un juge éloquent, ensevelies dans les urnes et les sépulcres de la mortalité» parce que les unes ne s’adressaient qu'aux seuls praticiens et que les autres ne publiaient que des réflexions spéculatives. Le directeur de la revue indique que l’orgueil de la revue sera de proposer les deux types de travaux...

Edinburgh Law Review, 2008, p. 26 s. qui reproduisent les contributions en langue allemande publiées dans M. Stolleis et T. Simon (éd.), Juristische Zeitschriften in Europa, Franckfort, Klostermann, 2006. Sur les revues juridiques aux Etats-Unis, Michael L. Swygert et John W. Bruce, «The historical origins, founding, and early development of student-edited law reviews», Hastings Law Journal, 1985, p. 752 s.; Richard A. Daner, «More than decisions: Reviews of American Law Reports in the pre-west era ", Duke Law School Public Law \& Legal Theory Series, 2015, p. 8 s.

14 «The subject of codification is one that falls very naturally within the plan of our publication, and one that hardly seems to be in its place either in the newspapers or literary reviews; though it has occupied some share in both, since we first began to hear of Jeremy Bentham» («Advertissement», The American Jurist, 1829, vol. 1, p. v).

15 «Advertissement», United States Law Intelligencer and Review, 1829, vol. 1, p. 5.

${ }^{16}$ Michael L. Swygert et John W. Bruce, «The historical origins, founding, and early development of student-edited law reviews», Hastings Law Journal, 1985, p. 752 s. 
avant que, fin 1833, la revue ne soit, à son tour, ensevelie dans les urnes et les sépulcres de la mortalité ${ }^{17}$. Malgré leur espérance de vie assez faible, ces revues britanniques et nord-américaines offrent à la controverse une place privilégiée. C’est une nécessité, un engouement, une mode éditoriale.

Les revues littéraires, quant à elle, sont publiées chaque trimestre (quarterly) pour l'édification du parfait gentleman qui, en homme accompli, s'intéresse aux arts et aux sciences dans leur diversité. On y propose donc des articles qui concernent aussi bien le droit que la littérature, la politique, les découvertes, l'économie, les langues, l'ingénierie technique, l'histoire ou la philosophie. Au Royaume-Uni, ces revues deviennent des tribunes pour traiter de la codification du common law, par exemple dans des revues radicales comme The Westminster Review et The Edinburgh Review l'ambassadeur des idées benthamites - ou dans une revue conservatrice comme The Quarterly Review. Aux Etats-Unis, The New York Review and Atheneum Magazine, The United States Review and Literary Gazette - deux revues du Nord, nées de fusions entre des revues antérieurement distinctes -, The National Intelligencer ou The Southern Review deviennent, elles aussi, des espaces pour la controverse.

En examinant ces revues, Richard A. Daner constate que, dans le premier $\mathrm{XIX}^{\mathrm{e}}$ siècle, la recension des décisions rendues par la cour suprême et les tribunaux des Etats va au-delà d'une publication strictement technique. Le commentaire des law reports constitue un forum pour discuter du droit, de ses sources, de ses fonctions dans la société américaine, notamment à l'occasion des débats sur la codification et la réforme du common law ${ }^{18}$. Le même phénomène s'observe au Royaume-Uni, lorsqu'on examine les textes publiés par la Westminster Review - tout, pour elle, tourne autour des «abuses» du droit anglais - ou par ses contradicteurs de The Quarterly Review. La question n'est pas seulement juridique, mais politique et sociale. D'où l'intérêt des abonnés. Prenons l'exemple de The North American. A l'origine du projet éditorial, il y a un groupe d'amis, parmi lesquels des membres d'Harvard, qui s'est donné pour mission de produire de la littérature. A l'époque, explique Julius $\mathrm{H}$. Ward, les élites nord-américaines publiaient de nombreux textes en matière politique et théologique, mais «la littérature américaine était encore dans l'enfance» ${ }^{19}$. Ce groupe, emmené par William Tudor, va rompre avec The Monthly Anthology pour fonder en mai 1815 une nouvelle revue dédiée aux humanités, semestrielle d'abord, trimestrielle ensuite. Elle a pour première vocation de publier de la poésie et des nouvelles. Très vite, le projet s'étend de sorte que le volume de 1829 justifie la publication d'un index général des vingt-cinq premiers volumes (1815-1827) par le fait que la revue a désormais pour vocation «d'embrasser une quantité et une variété telles de sujets, aussi bien à propos d'informations pratiques que de critiques, qu'un index général [...] apparaît essentiel pour toute utilisation valable et approfondie du travail» ${ }^{20}$. Aux alentours de 1820, la revue a acquis une telle notoriété qu'elle devient un lieu privilégié pour les questions disputées comme l'impôt fédéral ou l'esclavage dans les Etats du Sud. Avant 1824, la revue avait déjà publié plusieurs travaux juridiques sur des matières juridiques en particulier ou sur des défauts du droit américain, mais c’est évidemment après

\footnotetext{
17 «Preface», United States Law Intelligencer and Review, 1830-1831, vol. 1, p. III.

${ }^{18}$ Richard A. Daner, «More than decisions...», loc. cit., p. 8 s.

${ }^{19}$ Julius H. Ward, «The North American Review», The North American Review, 1915, vol. 201, p. 123.

20 «Note - Index to the first twenty-five volumes of the American Review», The North American Review, 1829, p. III.
} 
l'Anniversary Discourse de Sampson que la controverse sur la codification se développera dans les colonnes de la revue.

\section{L'outil: la recension}

Lorsqu'il contribue à une revue, qu'elle soit littéraire ou juridique, l'auteur aborde la controverse de façons diverses. Il peut relayer une information, par exemple The Legal Observer and Solicitors de novembre 1830 qui présente les huit résolutions votées en août par la Society of Practitioners in the courts of Law and Equity dont l'une, la dernière, témoigne de la peur à l'égard des annonces récentes et dénonce «l'adoption hâtive de systèmes inconnus sous l'appellation fallacieuse de réforme nécessaire et pratique ${ }^{21}$. Il peut aussi profiter d'un commentaire à propos d'une proposition de réforme, d'un débat, d'une nouvelle venue de l'étranger, du décès d'un éminent collègue. Mais l'outil privilégié demeure le compte-rendu: un ouvrage, un law report, un texte législatif ou un projet. A la vérité, la recension consiste moins à présenter le résumé, les qualités et les défauts du texte recensé, qu’à offrir au lecteur les réactions du contributeur sur le thème abordé par l'auteur. On comprend immédiatement comment la controverse sur la codification a pu exacerber le procédé en transformant chaque compte-rendu en autant d'occasions de soutenir ou d'agresser l'auteur du texte recensé et, à travers lui, le système juridique qu'il défend. D'autant qu'à l'époque, la règle dans les revues britanniques et nord-américaines - contrairement aux revues françaises - est l'anonymat. L’idée est qu'il est prétentieux, voire vulgaire, de signer son texte notamment dans un compte-rendu parce que le contributeur doit s'effacer devant l'auteur de l'ouvrage recensé ${ }^{22}$.

Ainsi, la recension d'un law report permet souvent à l'auteur de défendre le common law contre ses détracteurs, de vanter le travail des juges et des reporters qui alimentent la connaissance et l'étude du common law ${ }^{23}$. De même, c'est par la recension des statuts discutés ou promulgués que la revue The American Jurist cherche à entretenir l'idée qu'un mouvement historique et universel est à l'œuvre: «a general impulse» ${ }^{24}$. Toutes les occasions semblent bonnes. Il s'agit, par exemple, d'interpréter le Statut britannique 9 Geo., IV, c. 31 qui amende et consolide les lois concernant les infractions contre les personnes, comme «a specimen of partial codification ${ }^{25}$, d'offrir, dans chaque volume, la longue liste des Etats qui nomment des commissioners chargés de réviser et compiler les statuts comme d'autant d'étapes «as to form a revised code» ${ }^{26}$, ou de recenser «the statute laws of Tennessee» en regrettant l'échec de la tentative de consolidation ${ }^{27}$. Il s'agit encore d'affirmer, en s'appuyant sur la revue

\footnotetext{
21 «Law Society», The Legal Observer or Journal of Jurisprudence, 1830-1831, vol. 1, p. 38.

${ }^{22}$ Richard A. Daner, «More than decisions...», loc. cit., p. 23.

${ }^{23}$ Quelques illustrations: Haven à propos des Reports of Cases argued and determined in the English Courts of Common Law de Sergeant et Lowber («English common law reports», The North American Review, 1825, vol. 21, p. 377 s.) ou Porter à propos des Reports of cases du second circuit de Paine («Reports of cases..., by Elijah Paine», The North American Review, 1828, vol. 27, p. 167 s.).

24 «Dane’s Abridgment», The American Jurist, vol. 4, 1830, p. 66.

25 «Legislation», The American Jurist, 1829, vol. 1, p. 363.

${ }^{26}$ Quelques illustrations: à propos du «Code or system on the title of executors and administrators» de la Caroline du Nord (The American Jurist, 1829, vol. 2, p. 399 s.), du «Revised Code of Ohio» (The American Jurist, vol. 5, 1831, p. 411 et The American Jurist, vol. 6, 1831, p. 412), ou du «Revised Code» de Pennsylvanie (The American Jurist, vol. 6, 1831, p. 206).

27 «The statute laws of Tennessee», The American Jurist, 1832, vol. 8, p. 314.
} 
britannique The Legal Observer de novembre 1833, qu' «un pas a récemment été fait vers un code de lois en Grande Bretagne, par l'appointement de commissaires pour examiner l'état de notre droit criminel ${ }^{28}$. En d'autres termes, les law reports, d'un côté, la révision des statuts, de l'autre, permettent aux controversistes de faire flèche de tout bois $^{29}$.

Cependant, c'est la recension d'ouvrages qui devient peu à peu le champ de bataille privilégié entre partisans et adversaires des deux systèmes juridiques, surtout lorsque l'auteur est suspecté d'alimenter un argumentaire plutôt qu'un autre. Un même ouvrage peut ainsi être tantôt accueilli et encensé, tantôt honni et rejeté. Lorsqu'on examine dix années de tempête éditoriale, on constate qu'une dizaine d'ouvrages concentre l'essentiel des affrontements:

Sampson, An Anniversary Discourse... showing the Origin, Progress, Antiquities, Curiosities, and Nature of the Common Law, New-York, 1824

Du Ponceau, A Dissertation on the Nature and Extent of the Jurisdiction of the Courts of the United States..., Philadelphie, 1824

Verplanck, Essay on the Doctrine of Contracts, New-York, 1825

Miller, An Enquiry into the Present State of the Civil Law of England, Londres, 1825

Dane, A General Abridgment and Digest of American Law, Boston, 18231829, 8 vol.

Kent, Commentaries on American Law, New-York, 1826, 4 vol.

Humphreys, Observations on the Actual Situation of English Laws of Real Property, with the Outlines of a Code, Londres, 1826

Scott, The Life of Napoleon Buonaparte, Emperor of the French, Londres, 1827, 9 vol.

Cooper, Lettres sur la Cour de chancellerie et quelques points de la jurisprudence anglaise, Londres, 1827

Bentham, Rationale of Judicial evidence, Londres, 1827, 5 vol.

Park, A Contre-Projet to the Humpreysian Code; and to the Projects of Redaction of Mess. Hammond, Uniacke, and Twiss, Londres, 1828

Hoffman, Legal Outlines, Baltimore, 1829

Eunomus [Park], Juridical Letters addressed to the Right Hon. Robert Peel, in reference to the present crisis of Law Reform, Londres, 1830

L'examen des recensions permet de percevoir, d'une part, que les ouvrages nord-américains occupent le devant de la scène de 1824 à 1826, avant que les publications britanniques ne monopolisent l'espace éditorial à compter de 1827, d'autre part que la plupart de ces ouvrages donnent lieu à des recensions de chaque côté de l'Atlantique ce qui a eu pour effet d'élargir l'espace de la controverse. De sorte qu'à compter de 1827, la controverse britannique se nourrit de la controverse nordaméricaine ${ }^{30}$. En sens contraire, à compter de 1829, les débats américains sont alimentés

\footnotetext{
${ }^{28}$ The American Jurist, 1834, vol. 12, p. 274.

${ }^{29}$ Notons que la recension de la révision des statuts offre, inversement, l’occasion aux adversaires de la codification d'alerter le lecteur sur les dangers ou les méfaits d'expériences téméraires et hâtives. Ainsi, Gardiner, dans The North American Review, à propos de la révision des lois de New York (1827, vol. 24, p. 193 s.) ou The United States Law Intelligencer à propos du code révisé de New York (1831, vol. 3, p. 101) ou The American Quarterly Review à propos du code révisé de Pennsylvanie (1833, vol. 13, p. 30). 30 «Progress of jurisprudence in the United States», The Jurist, 1827-1828, vol. 1, p. 22 s.: «Government of the United States of America», The Westminster Review, 1828, vol. 10, p. 51 s.: «Codification of the Laws of the United States of America», The Jurist, 1828-1829, vol. 2, p. 47 s.: «Law reform in America 
par les débats britanniques ${ }^{31}$. Les champions américains sont enrôlés au Royaume-Uni, au même titre que les champions britanniques vont progressivement être connus, reconnus et mobilisés aux Etats-Unis. En d'autres termes, le contenu des revues permet de diffuser réciproquement les argumentaires nord-américains et britanniques, de rapprocher et les commonlawyers et les codifiers des deux continents.

L'examen des recensions montre encore que l'ardeur de la controverse concourt parfois à oublier à peu près complètement l'ouvrage qu'il s'agit de recenser... Cette façon d'opérer se concrétise dans une foule d'attitudes diverses. Dans l'Atlantic Magazine de février 1825, Sampson annonce vouloir recenser et The English Practice de Sedgwick (1822), et la Dissertation de Du Ponceau (1824). Toutefois, après avoir longuement répliqué à ses contradicteurs, Sampson achève son article sans avoir écrit un mot sur l'ouvrage de Sedgwick ${ }^{32}$ :

«Nous conclurons, écrit-il, en recommandant fortement la lecture de The English Practice, le premier travail en entête de cet article, où plusieurs abus de la pratique très faciles à corriger sont signalés avec franchise et précision. Le fait qu'il soit imputé à la plume de Mr Henry Sedgwick est en soi la meilleure des recommandations.»

En janvier 1831, The American Jurist propose une recension De la codification en général, et de celle de l'Angleterre en particulier de Meyer (1830) où le recenseur ne dit pas un mot de l'ouvrage mais propose une courte synthèse de la controverse allemande entre Thibaut et Savigny ${ }^{33}$... En août 1831, Hugh Legare entame la recension de A history of English law de Crabb (1831) en indiquant: «Nous profitons de la sortie de cette Histoire du common law - un abrégé sans envergure ni vraisemblance - pour dire quelques mots de ce grand sujet qui a saisi le pays: la codification», avant d'attaquer «Bentham and his followers» et ne plus jamais reparler de l'ouvrage recensé ${ }^{34}$. La controverse a son outil essentiel: la recension. Elle a aussi ses armes, légitimes ou pas...

\section{Les usages: les arguments, la modération, la loyauté}

Aussi bien aux Etats-Unis qu'au Royaume-Uni, les contradicteurs ont conscience qu'ils participent à une controversy, une notion qui, dans les revues des années 1820-1835, renvoie toujours à des cases, c'est-à-dire à des affaires disputées entre lawyers. Pour nos contributeurs - ce sont pour l'essentiel des praticiens du bar ou du bench -, une controverse s'apparente autant à l'art de défendre une cause à l'occasion d'un procès qu'à un débat entre philosophes, parlementaires ou journalistes.

\footnotetext{
», The Legal Observer, 1830-1831, vol. 1, p. 353 s.: «Law reform in America», The Law Magazine, 1831, vol. 6, p. 127 s.: «American law reforms», The Westminster Review, 1832, vol. 16, p. 359 s.

31 «Law of real property», The American Jurist, 1829, vol. 1, p. 58 s.: «Law of tenures», The Southern Review, 1829, vol. 3, p. 1 s.: «Law of real property», The United States Law Intelligencer and Review, vol. 1, 1829, p. 351 s.: «Bentham's Judicial Evidence», The Southern Review, 1830, vol. 5, p. 381 s.: «Meyer - On the judicial institutions [où l'auteur traite aussi d'Humphreys]», The Carolina Law Journal, 1830, vol. 1, p. 283-284: «Eunomus’s Letter», The American Jurist, 1831, vol. 5, p. 211 s.: «Written and unwritten systems of law», The American Jurist, 1833, vol. 9, p. 5 s.: «Revised code of Pennsylvania [où l'auteur commence par une recension de l'ouvrage d'Humphreys]», The American Quarterly Review, 1833, vol. 13, p. 30 s.

32 Sampson, «The common law», The Atlantic Magazine, 1824-1825, vol. 2, p. 292.

33 «Written and unwritten systems of laws», The American Jurist, 1831, vol. 5, p. 23-24.

${ }^{34}$ Legare, «Codification», The Southern Review, 1831, vol. 7, p. 391-392.
} 
Cet art s'apprend grâce à la fréquentation des classiques, grâce à la formation reçue auprès des avocats expérimentés, grâce au célèbre ouvrage du juriste Edward Wynne, Eunomus or, Dialogues concerning the Law and Constitution of England, with an Essay on Dialogue / Eunomus ou dialogues concernant le droit et la constitution d'Angleterre, avec un essai sur le dialogue. Dans les quatre volumes édités en 1768 et réédités à quatre reprises - la cinquième date de 1822 -, l'auteur défend le common law, ses principes et son fonctionnement, contre ses détracteurs comme s'il participait à un procès, en prenant pour jury l'opinion publique anglaise. La préface de la première édition et l'essai sur le dialogue livrent la méthode qui consiste, à partir de Platon, Aristote, Cicéron et quelques grands auteurs anglais, à convaincre les Anglais, en imitant une conversation argumentée entre contradicteurs ${ }^{35}$. Durant la Codification Controversy, il s'agit d'être «les avocats» de l'un ou l'autre système, de «supporter» ou de «plaider» l'une ou l'autre «cause», «d'avocater» («to advocate») en faveur du le common law ou de la codification ${ }^{36}$. A l'époque, il existe par conséquent, sinon une procédure, du moins une façon de faire, avec ses usages et ses principes, quoique beaucoup de contradicteurs soient prompts à dénoncer chez leurs adversaires ce qu'ils se permettent eux-mêmes de faire.

Il est très clair, en premier lieu, qu'il s'agit pour tous d'une bataille de mots, de discours, d'arguments, de formules, avec une part plus ou moins grande de mauvaise foi. En janvier 1829, par exemple, la revue anglaise The jurist entame une recension par ces mots ${ }^{37}$ :

« Ceux qui se font avocats de la formation d'un code, ou d'un système écrit de lois, doivent se contenter de partager le sort de tous ceux qui ont le courage de proposer ou d'approuver tout changement ou toute modification efficace des formes et des usages actuels - tout schéma global d'amélioration nationale. Ils doivent s'attendre à être confrontés à un régiment d'adversaires, armés de tous les instruments offensifs de la guerre verbale [offensive instrument of wordy warfare] - des arguments, des déclamations, des invectives, des railleries, des abus et surtout des fausses déclarations. »

\footnotetext{
${ }^{35}$ Eunomus or, Dialogues concerning the Law and Constitution of England, with an Essay on Dialogue, Londres, 1822, 5 ème éd., 4 vol., p. III, p. 15 s.

${ }^{36}$ Quelques illustrations: «In soliciting admission for the common law into the seats of academical learning, where its rival, the civil law, had long been a favoured inmate, no advocate ever pleaded his cause with more eloquence and grace...» (Sampson, An anniversary discourse... showing the origin, progress, antiquities, curiosities, and nature of the common law, New-York, 1824, p. 9): «The advocates of reformation...» (Grimke, An Oration on the Practicability and Expediency of Reducing the Whole Body of the Law to the Simplicity and Order of a Code, Charleston, 1827, p. 8): «Those who advocate Codification...» (Park, A Contre-Projet to the Humphreysian Code: and the Projects of Redaction of MM. Hammond, Uniacke, and Twiss, Londres, 1827, p. xv): «I shall now proceed to notice the latest work, avowedly advocating Codification, or rather an entirely new system» (Reddie, A letter to the Lord High Chancellor of Great Britain on the Expediency of the Proposal to Form a New Civil Code for England, Londres, 1828, p. 54): «Mr. Bentham in this country, and M. Meyer in Holland [...] are strenuous advocates for the formation of codes» («Court of Chancery», The Foreign Quaterly Review, 1830, vol. 5, p. 621).

37 «Those who advocate the formation of a code, or written system of laws, must be satisfied to share the lot of all, who have courage to propose or countenance any effective change or modification of existing forms and usages - any comprehensive scheme of national improvement. They must expect to encountered by a host of adversaries, armed with every offensive instrument of wordy warfare - with argument, declamation, invective, ridicule, abuse, and above all, with misrepresentation. Powerful are the passions, deep-rooted the prejudices, and multifarious the interests arrayed against them» («Written and unwritten law», The Jurist, 1828-1829, vol. 2, p. 181).
} 
Entame d'article fracassante car, évidemment, l'auteur identifie tous les siens comme des victimes, alors qu'il est lui-même l'agresseur. Il fixe en effet ses ennemis dans d'horribles catégories («sordid practioners», «supertitious formalist», «preacher of legal optimism»), et les qualifie d'hommes avec lesquels il est impossible d'argumenter «car ils ne savent jamais quand ils sont réfutés».

Il est admis, en deuxième lieu, que chacun devrait, en principe, débattre avec modération. La revue américaine The Atlantic Magazine pressent le danger des recensions et des répliques en chaîne dès le mois de février 1825. Alors que Sampson s’apprête à répondre à tous ses contradicteurs, les éditeurs fixent leurs conditions ${ }^{38}$ :

«On verra que, dans de nombreux domaines de la science politique et économique, les rédacteurs de ce journal dévoilent sans crainte et sans équivoque les doctrines qu'ils sont déterminés à défendre. La liberté du commerce et la liberté des opinions sont les principes auxquels ils sont ardemment attachés et dont aucune considération ne saurait les faire dévier. Mais il y a des questions moins générales, quoique à peine moins importante, sur lesquelles une différence d'opinion prévaut parmi les contributeurs de ce journal. L’opportunité de codifier nos lois actuelles est l'une de celles-ci; et à ce sujet, nous invitons à la plus libre et la plus ample des discussions, laissant aux contradicteurs le choix parmi les armes légitimes de la controverse.»

Qu'entendent-ils par «the legitimate weapons of controversy»? Lors de la recension des Documents accompagnant le projet de loi introduit par le comité judiciaire de l'Etat de New York sur la révision des lois (avril 1825), une note insérée par les éditeurs donne la clef: «Les directeurs de l'Atlantic Magazine croient nécessaire de faire observer que les pages de leur journal seront toujours ouvertes à une discussion tempérée à propos des principes et des vues invoqués à propos d'un projet d'une telle importance que celle de la révision codifiée des lois des Etats» ${ }^{39}$. Cela signifie que les directeurs de la revue prennent officiellement position en faveur de la réforme, mais qu'ils tiennent à la modération des propos...

Il est admis, en troisième lieu, que le contradictoire doit fonctionner avec loyauté. Alors que la controverse britannique fait rage, Humphreys contre-attaque dans la revue The Jurist en publiant une réplique en mai 1828. A propos de Reddie, son adversaire, il affirme qu' «usant d'un nouveau mode de controverse, il ne cite jamais mon travail lui-même mais la réponse que j'ai apportée dans ma lettre à Sugden» ${ }^{40}$. C'est un procédé déloyal... A la suite de cet article, la revue, qui milite en faveur de la codification, reçoit une étrange demande de la part de Reddie. Celui-ci souhaite répliquer à la contre-attaque d'Humphreys. Que doivent faire les éditeurs de la revue ? Publier la réplique, ce qui va à l'encontre de leur ligne éditoriale? La refuser, au risque

\footnotetext{
38 «It will be seen, that in many matters of political and economical science, the Conductors of this Journal have fearlessly and unequivocally avowed the doctrines they have determined to maintain, Free Trade and Free Opinion are the principles to which they are ardently attached, and from which no sort of consideration will ever induce them to swerve. But there are questions less general, though scarcely less important, respecting which a difference of opinion prevails among those who contribute to the pages of this Journal. The expediency of codifying our existing laws is one of these; and on this subject we invite the freest and fullest discussion, leaving to the disputants the choice of any of the legitimate weapons of controversy» (The Atlantic Magazine, February 1825, 1824-1825, vol. 2, p. 281).

39 The Atlantic Magazine, 1824-1825, vol. 2, p. 458, note.

40 «A Letter from Mr. Humphreys in Reply to Dr. Reddie and Mr. Cooper», The Jurist, 1828-1829, vol. 2, p. 130.
} 
de trahir les règles traditionnelles de la controverse? Ce serait un procédé déloyal... En janvier 1829, ils se décident donc à la faire paraître, accompagnée de cette note ${ }^{41}$ :

«Après avoir publié la lettre de $\mathrm{M}$. Humphreys, nous nous sentons tenus d'insérer la réponse [insert the answer] du Dr Reddie, bien que sa teneur générale soit directement opposée à nos opinions déclarées. Nous devons également saisir cette occasion pour exprimer notre regret du fait que des questions personnelles interfèrent, de chaque côté, avec une question de controverse juridique. - Eds.»

De son côté, The Law Magazine, va choisir de défendre les adversaires d'Humphreys en parlant de fair-play ${ }^{42}$ :

«L'amour du fair-play nous a d'abord incités à participer à cette controverse, et les mêmes motifs nous poussent à y participer de nouveau: nous avons consciencieusement recommandé les publications de $\mathrm{M}$. Park et du $\mathrm{D}^{\mathrm{r}}$ Reddie, et nous ferons de notre mieux pour les sauver de la déformation [des propos]. Ces deux messieurs ont été assaillis avec une férocité certaine, dont, du moins en ce qui concerne ce dernier, nous sommes bien loin de comprendre la cause.»

Toutes ces formules ne doivent nullement masquer la réalité. En fait, on invoque les règles de la controverse parfois pour prévenir un danger, le plus souvent pour discréditer l'adversaire. L'ardeur de la controverse devient telle que toutes les armes, y compris les armes illégitimes, sont requises: la démesure, les moqueries, les attaques ad nominem, et ce d'autant plus que - rappelons-le - la règle, dans les revues britanniques et nord-américaines, est l'anonymat, contrairement aux revues françaises où l'on demande aux auteurs de signer leurs contributions ${ }^{43}$. Pour incarner cette propension à l'outrance, prenons l'exemple de l'Essay on the Doctrine of Contracts.

\section{L'hystérie: l'exemple de l'Essay on the Doctrine of Contracts de Verplanck}

Gulian C. Verplanck a grandi au sein d'une famille de congressmen. Diplômé d'un bachelor of arts de Columbia en 1801, il est reçu au barreau en 1807, mais il ne pratiquera pas. Il s'intéresse plutôt aux arts et à l'écriture (au sein notamment de The North American Review), ainsi qu'à la philosophie et à la politique. Elu député au sein de l'Assemblée de l'Etat de New-York en 1820, réélu en 1822 et 1823, il poursuit sa carrière politique en tant que député à la Chambre des représentants du Congrès des Etats-Unis (quatre mandats de 1825 à 1833) ${ }^{44}$. En 1825, il publie son Essay on the

\footnotetext{
41 «Having published the letter of Mr. Humphreys, we feel ourselves bound to insert the answer of Dr. Reddie, although its general tenor is directly opposed to our avowed opinions. We must also take this opportunity of expressing our regret, that any personal asperity should have been intermixed, on either side, with a matter of juridical controversy. - Eds» («Dr. Reddie’s observations on Mr. Humphreys’s "Reply" ", The Jurist, 1829, vol. 2, p. 306, note).

42 «A love of fair play first induced us to take part in this controversy, and the same motives induce us to join in it again: we conscientiously recommended Mr. Park's and Dr. Reddie's publications, and we will do our best to save them from perversion. Both these gentlemen have been assailed with a degree of ferocity, which, so far at least as the latter is concerned, we are quite at a loss to account for» («Codification Controversy», The Law Magazine, 1829, vol. 2, p. 227).

${ }^{43}$ Richard A. Daner, «More than decisions...», loc. cit., p. 23.

44 «Verplanck», John A. Garraty et Mark C. Carnes (dir.), American National Biography, Oxford, Oxford University Press, 1999, 24 vol., vol. 22, p. 332.
} 
Doctrine of Contracts / Essai sur la doctrine des contrats comme une réaction contre le manque de rationalité des juges, comme un plaidoyer moral contre le système anglais de caveat emptor, comme une tentative scientifique d'adapter le complexe droit des contrats à l'économie américaine. Stevens J. Mathias, dans son étude sur la pensée juridique américaine, en fait, à côté de Joseph Story, Thomas Cooper et Hugh Legare, l'un des quatre profils type parmi les juristes qui, dans les années 1800-1860, cherchent à faire du droit une science, ordonnée et rationnelle ${ }^{45}$. Or, chemin faisant, Verplanck montre nettement sa préférence pour le civil law, dans sa double version romaine et française $^{46}$. Dans le troisième chapitre, Verplanck se félicite ainsi de voir le contrat de vente fondé, selon Pothier, sur le droit naturel. Il en déduit qu'il s'agit d'un système de droit beau et cohérent («a consistent and beautiful system of law») puisqu'il commence l'étude du contrat par l'examen de la cause, de la lésion ou des vices cachés. Tout cela, synthétise Verplanck dans son huitième et dernier chapitre, pourrait servir à améliorer le common law et faire du droit une science plutôt qu'un conglomérat de règles. Dans cet Essay, Verplanck ne s'aventure pas sur le terrain de la codification, mais parce qu'il admire le contenu du civil law, il va être suspecté de faire partie des disciples de Bentham et des admirateurs du code Napoléon. De sorte que, l'ouvrage publié, les partisans des deux systèmes juridiques s'emparent de l'essay et de son auteur, tantôt pour en vanter les vertus, tantôt pour les dénoncer comme sacrilèges, souvent pour régler des comptes avec d'autres auteurs, ce qui occasionne une bataille générale dans les revues qui, toutes ou presque, publient des recensions de l'Essay.

Dans un compte-rendu de janvier 1826, le contributeur anonyme du New York Review and Atheneum Magazine commence sa recension de l'Essay de Verplanck en attaquant un autre auteur, coupable, selon lui, d'une recension d'un autre ouvrage (Haven sur les Reports of Cases argued and determined in the English Courts of Common Law de Sergeant et Lowber) parue dans The North American Review d'octobre $1825^{47}$. Parce qu'Haven a défendu le common law, le second s'exclame ${ }^{48}$ :

«Nous ne pouvons pas laisser passer cette occasion d'exprimer notre désaccord avec une doctrine que nous avons souvent vue vaguement énoncée, mais qui a récemment été formellement avancée, expliquée de manière détaillée et appuyée dans un travail pour lequel nous exprimons le plus grand respect, et dont nous avions compris que nos opinions sur le sujet étaient plus libérales et plus précises que celles qui semblent avoir été interprétées par l'auteur de l'article en question. Nous faisons allusion à l'essai intitulé English Common Law Reports, publié dans le dernier numéro d'octobre de The North American Review.»

\footnotetext{
${ }^{45}$ Steven J. Macias, Legal Science in the Early Republic: The Origins of American Legal Thought, Lanham, Lexington Book, 2016, p. 65 s.

${ }^{46}$ W. Holt, Essays in Nineteenth-Century American Legal History, Westport, Greenwood Press, 1976, p. $230 \mathrm{~s}$.

${ }^{47}$ «Verplanck’s Essay», New York Review and Atheneum Magazine, vol. 2, 1825-1826, p. 105 s.; Haven, «English common law reports», The North American Review, 1825, vol. 21, p. 377 s.

48 «We cannot omit this opportunity to express our dissent from a doctrine which we have often seen vaguely stated, but which has lately been formally brought forward, and elaborately explained, and supported in a work for which we express the highest respect, and whose previous opinions upon this subject, we had understood to be more liberal and accurate, than those which appear to be entertained by the writer of the article in question. We allude to the essay, entitled English Common Law Reports, in the last October number of the The North American Review» («Verplanck’s Essay», loc. cit., p. 106).
} 
L'auteur critique l'argumentaire d'Haven, ridiculise certaines décisions des juges de common law en matière contractuelle, avant de revenir à l'Essay de Verplanck pour en dire du bien: «Nous inclinons fortement à être d'accord avec Mr. Verplanck dans la préférence qu'il donne au civil law dans ce cas particulier. Cela coïncide avec les sentiments de l'équité» ${ }^{49}$.

En avril 1826, Wheaton, après avoir marqué son hésitation entre common law et codification, explique combien il apprécie «the Essay before us», parce qu'il faut toujours «accorder de l'intérêt à ceux qui conçoivent le droit comme une science fondée sur la raison et qui ne se reposent pas simplement sur les institutions positives et sur l'autorité des précédents.» Plus loin, le contributeur agrée la position de Verplanck qui, dans le huitième chapitre, condense les principes et les axiomes du civil law, non, précise Wheaton, pour en faire un projet de code écrit, mais pour résumer sa pensée et l'offrir comme autant de moyens d'améliorer notre droit des contrats ${ }^{50}$.

Place à la réplique... En avril 1826, une longue recension d'une cinquantaine de pages paraît dans The United States Law Journal and Civilian Magazine, au cours de laquelle l'auteur anonyme en profite pour abreuver d'injures, de menaces et de sarcasmes tous les tenants de la codification ${ }^{51}$. A propos de l'Essay, lui-même ${ }^{52}$ :

«Pour tout ce qui touche au droit, nous le condamnons entièrement, et, même en tant que traité d'éthique, nous le croyons de nulle valeur. Pour ceux de nos lecteurs qui ne l'auraient pas encore acheté, nous voudrions recommander de le laisser tel quel sur les étals des libraires et, pour ceux qui l'ont acheté mais qui ne l'ont pas encore parcouru, notre conseil est de le laisser posé sur leurs tables, avec les pages non coupées.»

Vis-à-vis de la codification, il parle d'une insurrection et de l'homme qui se tient à sa tête ${ }^{53}$ :

«Ce Jeremy Bentham, un philosophe frappé et archi-codificateur; un homme, selon notre jugement, si totalement fou, que nous pensons réellement qu'il serait de bonne justice de l'enfermer et de le garder au pain et à l'eau jusqu'à ce qu'il soit amené, du fait de l'épuisement, à une maîtrise tolérable du sens commun.»

Au fil des pages, l'auteur associe Verplanck, Sampson et tous leurs disciples («un groupe d'hommes qui nous fatiguent continuellement avec leurs lettres ouvertes publiées dans les journaux et leurs longs articles dans les magazines»), dans un même ensemble d'ennemis à abattre et de voix à faire taire:

\footnotetext{
49 «We strongly incline to agree with Mr. Verplanck, in the preference which he gives to the civil law in this particular. It coincides with the natural sentiments of equity» (Ibid., loc. cit., p. 114).

${ }^{50}$ Wheaton, «Verplanck's Essay on Contracts», The North American Review, 1826, vol. 22, p. 256 et p. 277-278.

51 «Doctrine of contracts», United States Law Journal and Civilian Magazine, 1826, vol. 2, p. 72 s.

52 «As far as relates to the law, we condemn it entirely, and, even as an ethical treatise, we think if of no value. To such of our readers as have not yet brought it, we would recommend to leave it untouched upon the shelves of the booksellers, and to those who have purchased it, but have not yet perused it, our advice is, to let it lie upon their tables, with the leaves uncut» (Ibid., p. 95).

53 «That crazy philosopher and arch codifier Jeremy Bentham; a man, in our judgment, so thoroughly mad that we really think it would be injustice to shut him up and keep him on bread and water until he sould be brought, by depletion, to some tolerable measure of common sense» (Ibid., p. 101). Sur ces diatribes et l'antibenthamisme des commonlawyers américains à l'occasion de la controverse, P. Miller, «The common law...», loc. cit., p. 465: M. Bloomfield, «William Sampson...», loc. cit., p. 245.
} 
«Nous espérons que lui [Verplanck] et son école resteront désormais silencieux, ou que, s'ils continuent à agacer le public avec leurs longs et ennuyeux débats à propos du civil law et des codes de Justinien, et du code Napoléon, et du code prussien, et de l'armée complète des codes et des commentaires dont ils parlent si savamment, ils s'adressent à des oreilles sourdes.»

Place à la contre-réplique... Dans une lettre ouverte à Charles Watt, insérée dans le recueil de textes publié en 1826 par Pishey Thompson, Sampson va résumer les pages les plus caustiques de cette recension avant de se faire un plaisir de plonger, lui aussi, dans la démesure, la dérision et la méchanceté. Morceaux choisis... Sampson fait remarquer que la revue, l'US Law Journal, a cessé de paraître en 1823 avant de renaître en 1826 par un transfert de la liste des auteurs, opéré par les anciens éditeurs auprès des nouveaux: mais, ajoute-t-il, c'est une chose de transférer une liste, c'en est une autre de transférer le stock de talents et d'intelligence d'un volume à l'autre... Plus loin, il se désole que l'auteur de la recension n'ait pas écrit sa mise à l'index de l'Essay de Verplanck en langue latine; cela aurait pu s'apparenter à une bulle du pape... Plus loin encore, il s'interroge sur la nature de l'acrimonie des commonlawyers ${ }^{54}$ :

«Je ne sais pas ce qui se passe dans les pays où l'ancien système anglais n'a jamais prévalu, mais l'affection passionnée et aveugle que certains nourrissent réellement et honnêtement pour les absurdités de ce système, et surtout pour ce qui en est le plus incompréhensible, m’a souvent étonné. C’est vraiment une maladie de l'intelligence, et il vaudrait la peine de savoir où se trouve son siège - dans le cœur, le foie ou le cerveau - et où ces antipathies sont engendrées et par quel processus impénétrable elles agissent sur le système nerveux et poussent la bile dans les extrémités sensorielles, produisant une intumescence et une inflammation dans ces régions, et une violence d'action ressemblant beaucoup aux diagnostics et aux symptômes externes de la maladie appelée le tic douloureux [en français dans le texte]. Ce serait un bon sujet s'il y avait un physiologiste audacieux, comme Vic d'Azir, par exemple, prêt à disséquer l'écrivain du United States Law Journal lorsqu'il lui tombera entre les mains, ce qui ne saurait être long puisqu'il aura sans doute une apoplexie lors de l'un de ses violents accès de rageuse colère.»

Il y a, dans cet échange de coups, trois degrés de lecture à considérer. Au premier niveau, les adversaires s'agressent mutuellement parce que l'hostilité et l'outrance du premier entraîne, par mimétisme, celles du deuxième et ainsi de suite. A l'inverse, lorsque Du Ponceau répond à Sampson, certes en le traitant d' «iconoclaste du droit» mais en soulignant aussi sa profondeur de vue et la justesse de ses remarques à

\footnotetext{
${ }^{54}$ «I do not know how it may be in countries where the old English system never prevailed, but the passionate and blind affection which some really and honestly entertain for the absurdities of that system, and most of all for what is most incomprehensible, has often astonished me. It is really a malady of the understanding, and it would be well worth knowing where the seat of it is - in the heart, the liver, or the brain - and where such antipathies are engendered, and by what inscrutable process they work upon the nervous system, and force the bile up into the sensorial extremities, producing intumescence and inflammation in those regions, and a violence of action much resembling in its diagnostics and external symptoms, the disease called the tic douloureux. Here would be a fine subject, if there were any enterprising physiologist, such as Vic d'Azir, for instance, to stand ready for dissection when the writer of the United States Law Journal shall fall into his hands, which cannot be long, as he will doubtless go off in an apoplexy in some of these violent paroxysms of crying anger» («Sampson to Watt», Thompson, Sampson's Discourse..., op. cit., p. 160-161).
} 
l'égard des premières coutumes barbares, il entraîne, par mimétisme, Sampson à lui répliquer sur le même ton amical, courtois et mesuré. Au deuxième niveau de lecture, il s'agit évidemment de faire de l'esprit, de manipuler la langue et la culture pour railler l'adversaire. Sampson, dans son discours, avait maltraité, avec dérision et érudition, les prêtres qui encensent et protègent les sacrés mystères du common law. L'auteur de l'US Law Journal rend coup pour coup en raillant Bentham, un homme à ce point fou qu'il faut l'enfermer au pain et à l'eau pour lui faire recouvrer le sens commun. Aussi est-il logique que Sampson propose la dissection de son adversaire pour connaître le siège de la maladie du common law ou qu'il compare l'auteur de l'US Law Journal à Malvolio, un personnage tiré de La nuit des rois de Shakespeare qui est à la fois malade d'amour et fanatique d'intégrité... Mais, à un troisième niveau de lecture, se loge malgré tout un certain nombre d'affirmations où le ton se durcit, où l'humour se change en venin, où la distance entre les contradicteurs (et leurs systèmes respectifs) se creuse de façon irréparable. Dans son discours, Sampson avait pris soin d'attaquer le common law sans attaque ad nominem et sans confondre les enragés de la tradition avec les humbles praticiens qu'il souhaitait joindre à sa cause. Puisque l'auteur de l'US Law Journal a bien spécifié que tous les apôtres des codes étaient des «fops, coxcombs, visionnaries» (dandys, muscadins, visionnaires) qui ne comprennent rien au droit, Sampson en vient à traiter tous les amoureux du common law comme autant de malades de l'intelligence parce qu'ils entretiennent avec naïveté les absurdités du système.

Place aux répliques faites aux contre-répliques... Le compte-rendu de l'US Law Journal fait, en 1827, l'objet d'une note enthousiaste de quinze lignes dans The New-York Litterary Gazette and American Athenaeum de 1827, où l'auteur indique que la recension «est l'un des meilleurs articles que nous ayons jamais lu dans un travail de cette nature. Nous ne pouvons nier qu'il est occasionnellement dogmatique et ultrasévère ${ }^{55}$. De même, en mars 1827 , la recension anonyme publiée dans les colonnes du premier numéro de The American Quarterly Review adopte une position tranchée, sur un ton académique. S'il faut saluer la publication d'essais qui portent sur l'amélioration du droit, «rien ne pourrait être plus imprudent et dangereux qu'un esprit d'innovation sauvage et irrépressible en matière de droit» ${ }^{56}$. Loin d'accorder de «l'intérêt à ceux qui conçoivent le droit comme une science fondée sur la raison», l'auteur de l'American Quarterly Review estime que Verplanck a tort de vouloir, sur le fondement du civil law, faire reposer la validité des contrats sur le critère moral du bien et du mal ${ }^{57}$ :

«Il nous semble qu'il y a une erreur radicale dans l'argument de M. V., selon lequel il existe une norme de "jugement moral" ou de "conscience" sauf dans des cas très clairs et vastes. Le tribunal de la conscience: l'impression du bien et du mal: la notion de morale, sur laquelle il fonde tant d'éléments de son système, ne peuvent être trouvés nulle part sous une forme ou un caractère fixes. Ceux-ci varient avec l'éducation, les habitudes, les passions et les

\footnotetext{
55 «The United States Journal N5», The New-York Litterary Gazette and American Athenaeum, 1827, vol. 2, p. 20.

56 «Doctrine of Contracts», The American Quarterly Review, 1827, vol. 1, p. 106 s.

57 «It seems to us to be a radical mistake in Mr. V.'s argument, that there is a standard of "moral judgment", or "conscience" except in very clear and broad cases. The tribunal of conscience; the impressions of right and wrong; the notion of morality, on which he builds so much of his system, are no where to be found in any fixed shape or character. These vary with education, habits, natural passions and propensities, feelings, strength of intellect, interests, and other causes and circumstances. To refer a question of "right and wrong" to such standards, would be to have no right or wrong" (Ibid., p. 110111).
} 
propensions naturelles, les sentiments, la force de l'intellect, les intérêts et d'autres causes et circonstances. Renvoyer une question de « bien et de mal » à de telles normes, reviendrait à n'avoir ni bien ni mal.»

Le grand problème, explique l'auteur - il s'agit du fil directeur de sa stratégie discursive - est que le droit de la vente ne doit pas se fondre dans la morale et la philosophie, qu’il est plus facile de spéculer sur le contrat que de légiférer pour des millions de situations concrètes. Or, sur ce point, continue-t-il en développant son propos, la doctrine du common law est suffisante et complète. Et, conclut-il, la doctrine du civil law, avec ses D’Aguesseau et ses Leibniz, est pleine de mauvaises surprises (p. 125 s.), ce qui lui donne l'occasion de stigmatiser sans le citer Bentham et les siens ${ }^{58}$ :

«L'éthique raffinée des gens civilisés peut sembler délicieuse au philosophe lequel, dans son cabinet, se rend heureux avec des rêveries sur la perfectibilité de notre nature et de notre condition: mais s'il allait dans les entrepôts ou sur les marchés, il découvrirait qu'on requiert des doctrines plus complètes et plus pratiques pour les affaires actuelles du genre humain.»

Ces recensions de l'Essay de Verplanck expliquent la prise de conscience de Gardiner, au début de l'année 1827, lorsqu’il prophétise «une formidable guerre». De fait, le conflit s'envenime au fur et à mesure que certains contradicteurs se figent dans une attitude «d'individualité inflexible» et qu'ils abusent de sarcasmes, de paroles blessantes ou de formules disproportionnées. Gardiner écrit en janvier 1827. A cette date, le conflit dans les revues est effectivement devenu général aussi bien au RoyaumeUni qu'aux Etats-Unis. Le cas le plus intéressant est celui de l'opposition entre deux revues dont les lignes éditoriales sont parfaitement antagonistes.

\section{LE CHOC DES LIGNES EDITORIALES. L'EXEMPLE DE THE JURIST V. THE LAW MAGAZINE}

Aux Etats-Unis, les revues admettent le débat au sein même de leurs colonnes. Certes une revue juridique comme The American Jurist adopte une profession de foi en faveur de la codification, tandis que The Southern Review penche nettement du côté du respect du common law. Toutefois, l'une comme l'autre acceptent à l'occasion des articles qui sont en opposition avec leurs lignes éditoriales. Au Royaume-Uni, chaque revue adopte une ligne éditoriale sans concession, où directeurs et contributeurs partagent une même vision des choses, où les articles consistent à distribuer des coups, à agresser le système adverse, à défendre le système privilégié. Les revues entrent ainsi en guerre, les unes en faveur de la codification, les autres en faveur du système de common law. L'intérêt de l'étude comparée de The Jurist et de The Law Magazine est que les deux revues naissent à quelques mois d'intervalle, la seconde étant en partie fondée pour faire pièce à la première. Le phénomène n'est pas isolé. La revue conservatrice The Quarterly Review, explique Gwenaël Guyon, avait été fondée en 1809 par l'éditeur londonien John Murray «afin de contrer l'influence néfaste de la pro-Whig Edinburgh Review sur l'opinion publique» ${ }^{59}$. L'antagonisme entre The Jurist et The Law Magazine se vérifie dans les professions de foi des fondateurs, dans le choix des

\footnotetext{
58 «The refined ethics of the civilian may be delightful to the philosopher - who, in his closet, makes himself happy with reveries of the perfectibility of our nature and condition; but if he will go into the warehouse, or in the exchange, he will find that some more plain and practical doctrines are required for the actual business of mankind» (Ibid., p. 127).

${ }^{59}$ G. Guyon, Les partisans de la codification..., op. cit., p. 78, note 270.
} 
thèmes abordés comme dans l'affaire des Pays-Bas qui oppose Humphreys à ses contradicteurs ${ }^{60}$.

\section{Les idées directrices respectives}

The Jurist, or Quarterly Journal of Jurisprudence and Legislation a été fondé par Sharpe $(\dagger 1843)$ en mars 1827 et édité à Londres, par Baldwin, Cradock and Joy. Sutton Sharpe est un francophile, un réformateur, un correspondant et ami de Jourdan (le directeur de $L a$ Thémis), de Mérimée, de Stendhal ${ }^{61}$. Il justifie la revue par le fait que l'Angleterre dispose de multiples journaux littéraires - pas une secte qui n'ait sa propre revue -, mais qu'il n'existe pas de revue dédiée à l'étude du droit en tant que science, alors même qu'à l'étranger, on compte des revues de ce type en France, aux Pays-Bas, en Allemagne - l'auteur cite évidemment La Thémis et la Zeitschrift de Savigny. Or, ajoute-t-il, le moment est particulièrement propice à la création d'une telle revue au Royaume-Uni ${ }^{62}$ :

«Le législateur a porté son attention sur l'état défectueux de notre code et les anomalies de notre système judiciaire: et diverses mesures de réforme sont à l'étude, qui, pour être efficaces, doivent être mûrement pesées, fréquemment discutées et soumises au test d'une critique minutieuse et approfondie. L'esprit public est inquiet, concerné par le sujet, et l'information est recherchée avec avidité. Un esprit, tendant à enquêter de façon rationnelle, semble également imprégner les praticiens du droit: il y a une disposition évidente parmi eux à étendre leurs points de vue au-delà des aspects techniques étroits de la profession et à se débarrasser des reproches que leur adresse un distingué écrivain, selon lequel "le droit est étudié en Angleterre plutôt comme un art que comme une science”.»

Bentham est cité sans être nommé. La revue, continue le fondateur, ouvrira ses colonnes à tout ce qui, jusqu'à présent, n’intéressait personne: les vrais principes de la législation, la philosophie du droit, les institutions juridiques des autres pays, le droit romain. La revue se penchera sur les décisions juridiques et l'administration de la justice dans le pays et dans l'empire, ainsi que sur les réformes discutées au parlement. Mais, par-dessus tout, la revue suivra les progrès dans les changements de notre code («alterations in our code») et les réformes de nos institutions judiciaires. De fait, la revue qui, déplore Sharpe, n'est pas encore capable de proposer des rubriques comme dans les revues du continent, s'ouvre, en mars 1827, sur des articles concernant les réformes criminelles au Royaume-Uni (p. 1-21), sur les progrès de la science du droit aux Etats-Unis à partir de la recension de cinq ouvrages dont celui de Sedgwick sur les défauts de la procédure civile anglaise et la Dissertation de Du Ponceau (p. 22-40), puis

\footnotetext{
${ }^{60}$ M. Lobban, The Common Law..., op. cit., p. 185 s.

${ }^{61}$ D. Gunnel, Sutton Sharpe et ses amis français, avec des lettres inédites, Paris, Honoré-Champion, 1925.

62 «The legislature has turn its attention to the defective state of our code, and the anomalies of our judicial system: and various measures of reform are in contemplation, which, to be efficient, must be maturely weighed, frequently discussed, and subjected to the teste of a minute and searching criticism. The public mind is anxious, directed to the subject, and information is sought with avidity. A spirit, also, of rational inquiry seems pervade the practitioners of the law: there is an evident disposition amongst them to extend their views beyond the narrow technicalities of the profession, and to shake off the reproach cast upon them by a distinguished writer, "that law is studied in England rather as an art than a science"» (Sharpe, «Advertisement», The Jurist, 1827-1828, vol. 1, p. IV).
} 
sur des informations et des recensions diverses, avant de faire la liste des projets qui ont été publiés ou discutés au parlement (p. 131 s.). Dans ce premier numéro, les défauts et les abus du système d'equity, de common et de statute law ainsi que les quatre modèles de réforme (la codification à la française, la codification benthamienne, les compilations romaines, la consolidation des statuts) sont omniprésents.

Sharpe avait choisi pour sous-titre de sa revue: Journal of Jurisprudence and Legislation. Lorsqu'en juin 1828, Hayward fonde The Law Magazine, il opte pour un sous-titre qui, en soi, résume sa préférence: Review of Jurisprudence (sans la Legislation). Abraham Hayward ( $†$ 1884) est le juriste qui, en 1831, traduira et publiera en anglais le Vom Beruf de Savigny sous le titre: Of the Vocation of our Age for Legislation and Jurisprudence. Il a alors vingt-sept ans. Il a intégré The Inner Temple en 1824 et s'est fait connaître en tant que polémiste conservateur ${ }^{63}$. Son idée principale est d'offrir à la profession une tribune, aussi bien pour discuter des abus constatés dans la procédure civile et l'organisation judiciaire, que pour combattre les réformes radicales et les tentatives de codification. L'ennemi préféré de la revue sera évidemment Jeremy Bentham. Le premier numéro s'ouvre sur un article d'une trentaine de pages autour des principes et de la procédure de pleading, à partir de la recension, pêle-mêle, du long discours où Brougham (le nouveau chancelier) propose de réformer et codifier le droit anglais, de la réplique à Brougham publiée par Peel, des suggestions faites par Sergeant à propos de la procédure civile, des attaques parues dans The Westminster Review, une revue radicale, concernant les abus du pleading. Le contributeur admet que le système traditionnel des actions est universellement condamné. Toutefois, il choisit de défier Brougham, Mill et Bentham ${ }^{64}$ :

«A une telle ribauderie, il n’y a aucun moyen de réponse que des personnes bien élevées puissent employer: mais nous nous efforcerons d'effacer une partie du reproche, en nous écartant largement de ce mode de défense couramment adopté par la profession. Nous ne chercherons pas à nous réfugier dans la technicité: nous n’assumerons pas la nécessité de formes particulières; mais descendons plutôt du terrain d'observation du précédent et des autorités, et rencontrons nos adversaires sur le terrain des principes de jurisprudence abstraite; et nous nous engageons à démontrer, aussi brièvement que possible, que, bien que confite d'une ingéniosité plus pervertie que le bon goût et la raison pourraient admettre, la plaidoirie anglaise est fondée sur des principes aussi solides que tous ceux que les réformateurs pourraient imaginer. Nous exposerons ses défauts aussi librement que nous revendiquerons ses avantages.»

De sorte que l'auteur vient chercher sur leur propre terrain les défenseurs de la codification. Avec leurs lubies, ils ne comprennent rien à la logique des précédents, leur

\footnotetext{
63 A. Chessell, The Life and Times of Abraham Hayward, QC. Victorian Essayist, Londres, Lulu Publishing, 2008.

${ }^{64}$ «To such ribaldry as this, there is no manner of reply which well-bred persons can employ; but we will endeavour to wipe away some part of the reproach, by departing widely from that method of defence which is commonly adopted by the profession. We shall not seek to intrench ourselves in technicality; we shall not assume the necessity of any particular forms; but descend at once from the vantage ground of precedent and authority, and meet our adversaries on principles of abstract jurisprudence; and we undertake to shew, with as much brevity as possible, that, though overloaded by perverted ingenuity with much that taste and reason would reject, English pleading is founded upon principles as sound as any that reformers can contrive. We shall expose its faults as freely as we shall claim credit for its advantages» («Principles and practice of pleading», The Law Magazine, 1828-1829, vol. 1, p. 2).
} 
variété, leur clarté, leur force explicative. Réclamant un code, et par conséquent de la simplicité, de la certitude et de la rapidité, ils sont, s’amuse-t-il, à l’image de ces aéronautes qui, pour prouver la facilité de se déplacer dans l'air, exigeraient, en amont, qu'on leur fournisse une machine permettant de monter, de descendre et de se diriger aisément, ou encore à l'image d'Archimède qui, pour prouver qu'on peut déplacer la terre, demandait qu'on lui désigne le bon endroit où se tenir pour la soulever. En d'autres mots, pour démontrer qu'il est possible de supprimer la complexité de la procédure civile, ils exigent qu'on les laisse libres de façonner leur code. La revue continue avec diverses informations et recensions sur les réformes en cours, par exemple les projets concernant la Court of Chancery ou la consolidation des statutes concernant la banqueroute, pour s'achever avec un digest des décisions de justice récemment rendues, la liste des statutes votés lors de la dernière session, l'état des commissions de réforme, et les évènements du trimestre. La tonalité générale est à minimiser les défauts du système juridique anglais et à contrecarrer les opinions des codificateurs. Ainsi, à propos de la Court of Chancery, l'auteur, sans jamais traiter des deux ouvrages dont il se proposait de faire le compte-rendu, décrit la cour et ses soucis, en les minorant, avant de conclure, avec Sugden, que le système fonctionne en fait aussi bien que possible ${ }^{65}$.

\section{L'affaire des Pays-Bas}

Le sujet qui va, dans l'immédiat, affirmer le clivage entre les deux revues est la question de savoir qui, d'Humphreys ou de Cooper et Reddie, a menti concernant la codification civile aux Pays-Bas. Retour sur une petite phrase qui devient l'enjeu d'un bras de fer et le cœur de la tactique argumentative de part et d'autre... En 1826, Humphreys s'était lamenté sur le fait que les Britanniques n'avaient pas encore mis en chantier un code civil, alors que les Pays-Bas avaient fait de considérables progrès et que les Etats pontificaux précédaient désormais le Royaume-Uni dans l'art de la législation ${ }^{66}$. Reddie, un défenseur du common law, lui avait répliqué qu'en fait de code, les Hollandais étaient retournés à leurs anciens droits, de sorte que ce texte, si hautement loué par Humphreys pour exiger des changements radicaux, n'était en fait qu'un retour aux lois et aux coutumes nationales ${ }^{67}$. Humphreys avait alors décidé d’aller en personne sur le continent, avait rencontré Van Mannen, le ministre hollandais, qui l'avait assuré que le nouveau code civil des Pays-Bas fonctionnait à merveille et qu'il avait l'avantage d'être plus récent que le code civil français. Humphreys avait rapporté tout cela dans la préface de la seconde édition de son ouvrage, en 1827. Mais en 1828, Cooper, un autre partisan du common law ${ }^{68}$, avait affirmé ne jamais avoir pu mettre la main sur ce fameux nouveau code civil des Pays-Bas. Il avait ajouté en s’appuyant sur un article de Blondeau paru dans la revue française La Thémis, qu'Humphreys avait dû confondre cet hypothétique code hollandais avec le code Napoléon adopté et conservé

\footnotetext{
65 «Reforms in Chancery», The Law Magazine, 1828-1829, vol. 1, p. 45.

${ }^{66}$ Humphreys, Observations on the Actual Situation of English Laws of Real Property, with the Outlines of a Code, Londres, 1826, p. 169-170.

${ }^{67}$ Reddie, A letter to the Lord High Chancellor of Great Britain on the Expediency of the Proposal to Form a New Civil Code for England, Londres, 1828, p. 39.

${ }^{68}$ Charles Purton Cooper ( $†$ 1873) est un Equity Draughtsman (spécialiste des questions d'equity) qui défend le common law (Stephen, Dictionary of National Biography, Londres, 1887, t. XII, p. 140 s.). Thomas Cooper († 1839) est un radical britannique qui a migré aux Etats-Unis, qui est devenu professeur et qui s'assume disciple de Bentham (Steven J. Macias, Legal Science..., op. cit., p. 117 s.).
} 
en Belgique ${ }^{69}$. Cooper avait ajouté que de nouveaux codes sont effectivement en chantier depuis 1814, mais que, pour l'heure, le code Napoléon est toujours en vigueur en attendant d'éventuels progrès législatifs.

En mai 1828, Humphreys s'adresse à Sharpe pour que la revue The Jurist publie sa réplique: A Letter from Mr. Humphreys in Reply to Dr. Reddie and Mr. Cooper. Il y résume les attaques de Reddie et Cooper. D'une part, il aurait prôné la codification. D’autre part, il se serait trompé dans ses références. Humphreys se défend âprement sur le premier point en reconnaissant que le mot code est propre à indisposer ceux qui réclament des réformes. Mais, ajoute-t-il, le fruit de la réforme peut aussi bien être appelé un code, une loi («an act»), une série de lois ou un amendement et une consolidation de lois; cela reste une querelle de mots. Sur le second point, il s'interroge. Comment Reddie peut-il affirmer que le nouveau code des Pays-Bas n'est qu'un retour aux usages d'Ancien Régime, puisque ce code et le code français sont aussi proches dans leur forme et leur contenu ${ }^{70}$ ? Deuxièmement, il faut se rendre à l'évidence: le Journal officiel des Pays-Bas a bel et bien publié le nouveau code, par morceaux, depuis le 14 juin 1822 jusqu'au 26 mars 1826. Troisièmement, il n'y a pas de confusion possible entre le code hollandais et le code belge puisqu'Humphreys n'a jamais eu ce dernier entre les mains. Humphreys termine sa lettre en rassemblant les erreurs, les omissions et les subterfuges de ses contradicteurs, avant d'égratigner Cooper sur ses paradoxes.

De son côté, évidemment, The Law Magazine est amené à donner du crédit à Reddie et Cooper. En 1828, sous le titre «Codification Controversy - Mis-statements and mistakes of Mr. Humphreys», la revue publie une recension, longue et louangeuse, du Contre-Project to the Humphreysian Code de Park, un autre avocat du common law. «Un très précieux travail», s’exclame le contributeur. Après avoir longuement cité et apprécié le texte, après avoir déclaré qu’Humphreys est un casuiste plein de dextérité, mais que la prochaine fois qu'il s'en prendra à Reddie, il vaudrait mieux qu'il relise les aphorismes de Bacon car certaines lignes pourraient le démolir («would demolish him»), le contributeur en vient à répliquer à la réplique publiée dans The Jurist: A Letter from Mr. Humphreys in Reply to Dr. Reddie and Mr. Cooper. Il s'agit, assure-t-il, du "plus beau spécimen de confusion que nous ayions jamais lu». L'auteur résume l'enjeu: Cooper a accusé Humphreys de ne pas avoir vu le code civil hollandais et pour cause, selon lui, il n'existe pas. Afin de défendre Cooper, l'auteur de la contre-réplique va d'abord se lancer dans de minutieuses recherches et contrer chacune des affirmations produites dans The Jurist. Il va ensuite longuement citer Park qui, dans son ContreProjet, éreinte Humphreys à propos de l'affaire des Pays-Bas. D’une part, Humphreys, en citant le Journal officiel, n'a pas compris que les dernières promulgations ne vont pas au-delà du Troisième Titre du Deuxième Livre, en sorte que le code, en tant que système complet, n'est pas encore entré en vigueur. D’autre part, Park étaye la thèse du mensonge ou de la méprise d'Humphreys. Il relate qu'il s'est rapproché du baron Falck, l'ambassadeur des Pays-Bas au Royaume-Uni, et d'Holtius, un professeur de Louvain, lesquels vivent actuellement à Londres. Ils lui ont expliqué qu'à l'exception du Titre concernant les baux emphytéotiques qui a été rendu applicable, le reste du projet de

\footnotetext{
69 Cooper, A Brief Account of some of the most important proceedings in Parliament, relative to the defects in the Administration of Justice, in the Court of Chancery, the House of Lords and the Court of Commissioners of Bankrupt, Londres, 1828, p. 431.

${ }^{70}$ «A Letter from Mr. Humphreys in Reply to Dr. Reddie and Mr. Cooper», The Jurist, 1828-1829, vol. 2, p. 131.
} 
code a été publié dans le Journal officiel «à titre provisoire», en attendant l'intégralité du texte. Par conséquent, c'est toujours le code Napoléon qui en vigueur aux Pays-Bas. «Alas, alas, Mr. Humphreys! se réjouit le contributeur, The Spanish fleet you cannot see / Because it is not yet in sight» Cette formule est un procédé littéraire classique pour dire d'un auteur qu'il a menti, qu'il ne peut pas avoir vu l'armada espagnole puisqu'elle n'est pas encore en vue ${ }^{71}$. Et le contributeur de promener la tête d'Humphreys au bout d'une pique ${ }^{72}$ :

«Et pourtant, vous avez systématiquement affirmé, non seulement que ce code fonctionnait bien, mais qu'il contenait tout le corps des lois sur la propriété, réelle et personnelle, en 518 pages octavo [...]. Votre erreur a été insinuée en termes aussi légers que possible: et quand M. Cooper a suggéré qu’aussi bien dans votre conversation avec $\mathrm{M}$. Van Maanen que dans votre critique, vous aviez confondu le Code belge avec le Nouveau Code civil des Pays-Bas, il a suggéré la seule excuse qui vous aurait permis d'éviter un naufrage complet; mais vous avez cru bon de répliquer avec acrimonie: vous, dont neuf-dixièmes des prétentions sont fondés sur la déformation [des mots], vous avez osé lui parler de déformation; et vous composez, pour vous-même, une défense [la lettre publiée dans The Jurist], dont vous porterez la honte jusqu'à la fin de votre vie. M. Park vous a presque anéanti.»

Cet assaut victorieux de The Law Magazine s'accompagne de la contre-contreréplique rédigée par Reddie en septembre 1828 qu'il réussit à faire publier dans les colonnes-mêmes de l'adversaire: The Jurist de janvier 1829. Reddie s'y défend de toutes les attaques personnelles faites par Humphreys, reprend l'idée que celui-ci a commis une grave erreur à propos de la Hollande, rend coup pour coup à propos de l'opportunité des codes $^{73}$. Que dire de ce cycle autour de l'affaire des Pays-Bas? Objectivement, Humphreys s'est trompé et a eu tort d'insister. Objectivement, son erreur n'enlève rien à ses observations sur les défauts du droit anglais de la propriété réelle. Objectivement, la victoire des ennemis de la codification est à nuancer: un code civil est bel et bien en chantier aux Pays-Bas. Il pourrait s'agir de beaucoup de bruit pour rien... Si ce n'est, d'une part, que lorsqu'on rapporte cette querelle à la controverse en tant que procès du common law devant le jury de l'opinion publique, les ennemis des codes peuvent légitimement crier victoire. Combien d'avocats plaident-ils sur le fond? Combien l'emportent-ils en démontrant un vice de forme ou de procédure dans le dossier adverse? Reddie, Cooper, Park et The Law Magazine ont rapporté la preuve d'un vice dans le dossier d'Humphreys. A leurs yeux, c'en est assez pour innocenter le

\footnotetext{
71 «The Herald criticism [à propos d'une erreur d'un critique du Morning Herald]», The Theatrical Inquisitor or Literary Mirror, 1812, vol. 1, p. 147; «Gaston de Blondeville with An Essay on the Life and Writings of Mrs. Radcliffe [à propos d'une omission de l'auteur, Colburn]», The London Magazine, 1826, vol. 6, p. 36.

72 «And yet, you have systematically avowed, not merely that this code worked well; but that it contained the whole corpus of the laws of property, real and personal in 518 moderate octavo pages [...]. Your mistake was hinted at in terms as mild as it was possible to use; and when Mr. Cooper suggested that both in your conversation with M. Van Maanen, and in your criticism, you had mistaken the Belgic Code for the New Civil Code of the Netherlands, he suggested the only excuse that could bring you off without a total wreck of character: but you thought proper to retort with acrimony: you, nine-tenths of whose claims are built on perversion, have dared to talk of perversion to him: and you compose a defence for yourself, the shame of which will stick to you for life. Mr. Park has nearly finished you» («Codification Controversy - Mis-statements and mistakes of Mr. Humphreys», The Law Magazine, 1828-1829, vol. 1, p. 634).

73 «Dr. Reddie’s observations on Mr. Humphreys’s “Reply”», The Jurist, 1829, vol. 2, p. 306 s.
} 
common law des accusations dont il a fait l'objet. Si ce n'est, d'autre part, que les argumentaires respectifs (le logos) sont portés par des hommes dont la stature (l'ethos) sort ou non grandie de l'affrontement. A ce moment précis (automne 1828-hiver 1829), il s'agit moins, pour une partie de l'opinion publique, de savoir qui a raison à propos de la codification ou du respect du common law, que de savoir qui, d'Humphreys ou Reddie et Cooper, s'est fourvoyé, qui de The Jurist ou The Law Magazine, a rapporté la vérité à propos du code civil des Pays-Bas, qui, des deux camps, a cherché à abuser le public. C'est un rapport de force, dont les effets sont considérables en termes d'antagonismes entre adversaires et, par conséquent, en termes d'appréciation des deux systèmes prônés et défendus.

\section{Le choix des recensions et des informations}

Un simple tour d'horizon comparatif permet de confirmer qu'au fil des numéros, les deux revues respectent leurs lignes éditoriales grâce au choix des informations qu'elles publient et des ouvrages qu'elles recensent. En 1829, The Law Magazine continue à accabler le pauvre Humphreys en publiant, tour à tour, deux terribles tribunes intitulée Codification Controversy et Letter on Mr. Humphreys ${ }^{74}$. De son côté, The Jurist survit à l'épisode des Pays-Bas en chargeant Reddie et Park à l'occasion d'une recension du Vom Beruf de Savigny qui a été utilisé par Reddie dans $A$ Letter to the Lord High Chancellor of Great Britain (1827, réed. 1828). Certains auteurs, assure le contributeur, approfondissent leurs recherches et se présentent en véritables contradicteurs - c'est le cas de Savigny -, d'autres en font le triomphe de la cour de récréation. Tel est le cas de Reddie qui a publié un ignoble («obnoxious») pamphlet, qui a utilisé le Vom Beruf en le rendant inintelligible, qui a multiplié les erreurs. L'analogie est méchante ${ }^{75}$ :

«Toutefois, nous ne sommes pas de sévères pourfendeurs des fragilités, humaines ou animales, et nous nous sommes toujours sentis charitablement disposés envers le chien de la ballade de Goldsmith, qui, pour convenir à ses desseins, est devenu fou. La provocation, probablement, était grande. Mais, quoique nous ayons de la compassion pour le chien, nous ne le considérons pas comme le plus discret des animaux à quatre pattes, ni comme le cerf de Sir Kenneth, dans Talisman de Scott. Sa faiblesse et son sort ont été embaumés dans une ballade, mais nous ne ferons pas de lui le héros d'une romance.»

Sur le même ton de raillerie et d'attaques personnelles, l'auteur frappe Reddie, puis Park, à coups redoublés. En avril 1829, The Jurist présente, en détails, la façon dont les codes français ont été rédigés, votés et promulgués ${ }^{76}$, expose les réformes en Louisiane à partir de la recension de quelques ouvrages et des informations offertes par The American Quarterly Review de septembre $1828^{77}$, puis publie la conférence

\footnotetext{
74 «Codification Controversy », « Letter on Mr. Humphreys», The Law Magazine, 1829, vol. 2, p. 227 s., p. $231 \mathrm{~s}$.

75 «Now, we are no harsh castigators of frailties, human or animal, and we have always felt charitably disposed towards the dog of Goldsmith's ballad, who, to suit his private ends, went mad. The provocation, probably, was great. But, though we compassionate the dog, we do not hold him up as the most discreet of four-footed animals, nor compare him to the stag-hound of Sir Kenneth, in Scott's Talisman. His weakness and his fate have been embalmed in a ballad, but we will not make him the hero of a romance» («Written and unwritten law», The Jurist, 1828-1829, vol. 2, p. 205).

76 «History of the French codes», The Jurist, 1828-1829, vol. 2, p. 341 s.

77 «Jurisprudence of Louisiana», The Jurist, 1828-1829, vol. 2, p. 434 s.
} 
qu'Humphreys a donné à l'Université - de Londres ${ }^{78}$. Puis, de 1830 à 1832, The Jurist connaît ce que la revue radicale The Westminster Review de 1832, appellera «une funeste interruption de deux années.»

De son côté, The Law Magazine continue à paraître. En 1830, on y recense les premières Juridical Letters d'Eunomus (Park), pour louer l'auteur et attaquer les thèses de Bentham ${ }^{79}$. Dans une recension de De la jurisprudence des arrêts de Dupin, il s'agit certes de décrier l'état du statute law en Angleterre, mais de conclure, grâce à Dupin et à Cooper, que c'est la même chose en France, en Allemagne ou aux Etats-Unis ${ }^{80}$. Dans une recension de The Life of Daguesseau de Butler (un ouvrage qui conclut sur le bienfondé des réformes de Peel), le contributeur en profite pour maudire l'auteur qui, d'un côté a fait connaître Humphreys en disant du bien de son travail dans une recension, qui, de l'autre, s'est toujours fait l'adversaire des $\operatorname{codes}^{81}$. En 1831, la revue profite de la recension de l'ouvrage de Cooper, pour tirer de la préface de Royer-Collard, la liste des défauts du système judiciaire français, le triste état du barreau et de la magistrature en France, l'extrême brièveté des codes... ${ }^{82}$. Dans une analyse de la révision des statutes opérée dans l'Etat de New-York, l'auteur défend les cours d'equity à l'Anglaise qu'il s'agit, en Pennsylvannie, de fondre avec les juridictions de common law ${ }^{83}$.

The Jurist reparaît en avril 1832, avec divers articles qui relatent les défauts du système judiciaire anglais, les évolutions législatives en France depuis la révolution de Juillet, une comparaison entre les procédures législatives en France et au Royaume-Uni, au détriment du second ${ }^{84}$. La revue salue le travail d'Austin, «dans un pays où, mis à part quelques bribes de Bentham, on ne se préoccupe pas du droit comme d'une science» ${ }^{85}$. En juillet 1832, elle propose de comparer l'administration de la justice en France et au Royaume-Uni, toujours au détriment du second. Puis elle s'offre de nouveau la dépouille de Park, devenu professeur à l’Université de Londres ${ }^{86}$ :

«Le professeur Park "promoteur de l'école naissante de politique inductive, ou de science politique observationnelle”, comme il se nomme lui-même, a fait, selon son propre récit, une grande découverte qu’il a annoncée au monde dans un ouvrage sous le titre fracassant rapporté ci-dessus. Il a découvert que tout le monde, sauf lui-même et Lord Dudley, s'était totalement trompé sur la nature et le génie de la constitution anglaise, dont l'excellence consiste en l'existence d'une Chambre des communes corrompue.»

Au fil de l'année 1832, The Law Magazine profite, quant à lui, de l'analyse du nouveau code de commerce espagnol, pour donner un coup de griffe aux codes antérieurs, soit qu'ils soient trop brefs, comme en France, soit qu'ils cherchent à

\footnotetext{
${ }^{78} \mathrm{Mr}$. Humphreys's lecture on the law of real property», The Jurist, 1828-1829, vol. 2, p. 469 s.

${ }^{79}$ «Juridical Letters... by Eunomus», The Law Magazine, 1830, vol. 3, p. 388 s.

80 «De la Jurisprudence des Arrêts... par M. Dupin», The Law Magazine, 1830, vol. 4, p. 1 s.

81 «Butler's Life of D’Aguesseau», The Law Magazine, 1830, vol. 4, p. 123 s.

82 «Lettres sur la Cour de Chancellerie... par C. P. Cooper», The Law Magazine, 1831, vol. 5, p. 50 s.

83 «Law reform in America. Advantages of equity courts», The Law Magazine, 1831, vol. 6, p. 151 s.

84 «Historical illustrations of the English law. $n^{\circ} 1$. - The judges », «Changes in French Law», "History of Law reform », The Jurist, 1832, vol. 3, p. 29 s., p. 37 s., p. 55 s.

85 «The Province of Jurisprudence... by John Austin», The Jurist, 1832, vol. 3, p. 105 s.

86 «Professor Park "the promoter of the nascent school of inductive politics, or observational political science", as he terms himself, has made, according to his own account, a great discovery, which he has promulgated to the world in a work bearing the above striking title. He has discovered that everybody, but himself and Lord Dudley, has totally mistaken the nature and genius of the English constitution, the excellence of which consists in the existence of a corrupt House of Commons» («The Dogmas of the Constitution... by J. J. Park», The Jurist, 1832, vol. 3, p. 105 s.)
} 
anticiper tous les cas possibles, comme en Prusse ${ }^{87}$. La recension de Boa Constrictor, un ouvrage consacré à l'absorption, par la Cour du chancelier, de la Cour du vicechancelier et de la Cour of the Master of the Rolls, permet à l'auteur de traiter des rapports entre Brougham, le chancelier, et Bentham. Ce dernier, reconnaît le recenseur, a été un auteur clair dans sa jeunesse, mais il ne l'est plus. Il ne s'adresse plus guère qu'à son école. Il reste en lui du génie, mais il devenu ridicule ${ }^{88}$. Quant à la recension du troisième rapport de la commission de réforme consacrée à la propriété réelle, elle permet à l'auteur d'affirmer, avec les commissaires, que la codification n'est pas souhaitable, car on obtiendrait les inconvénients sans aucun des avantages ${ }^{89}$. L'analyse des codes pénal et d'instruction criminelle entraîne l'auteur à citer de longs passages pour montrer, qu'en France, lors des interrogatoires, la torture physique a disparu, mais pas la torture mentale ${ }^{90}$.

En 1833, est publié le dernier volume de The Jurist - la publication ne dépasse pas le mois de février -, mais déjà l'énergie des origines semble s'être évanouie. La codiphilie, qui était la marque de fabrique de Sutton Sharpe, fléchit peu à peu. A l'occasion de la recension du troisième rapport de la commission de réforme consacrée à la propriété réelle, le contributeur cite - comme The Law Magazine, la revue ennemie - le passage dans lequel les commissaires, estiment que la codification ne serait pas souhaitable, puisqu'on en tirerait les inconvénients sans les avantages. Le contributeur doit admettre que, vu de cette façon, ils n'ont peut-être pas tort ${ }^{91}$. A l'occasion du compte-rendu de l'ouvrage de Légat sur du Traité de la législation française concernant les étrangers (1832), le recenseur reconnaît avec l'auteur, que l'absence de jurisprudence claire sur le sujet «prouve que la codification n'a pas encore parfaitement rempli sa mission en France» ${ }^{92}$.

Pour sa part, The Law Magazine de 1833 continue sur le même rythme et sur le même ton. Afin d'introduire the Spa-Fields Verdict, à propos de l'homicide, la revue défend le droit anglais contre ses détracteurs: «Cela a été un des sujets favoris de reproche contre le peuple anglais que, quoiqu'il vante l'excellence supérieure de ses lois, la plupart d'entre eux sont aussi ignorants de leur nature que la nation la plus mal gouvernée d'Europe». Les uns, résume le contributeur, l'expliquent par le manque d'éducation, d'autres, «theorists in code-making», le rapportent à la confusion et l'incertitude inséparables d'un droit non écrit fabriqué par le juge («unwritten judgemade law»), d'autres encore, spécialistes de morale, le résument à l'égoïsme des juristes qui ont intérêt à garder pour eux les éléments de cette science. Toujours est-il, continue l'auteur, que le droit anglais a prospéré et si l'on avait à en sélectionner un seul exemple, ce serait celui du droit concernant l'homicide ${ }^{93}$ :

«Clair, juste et raisonnable dans sa nature, clair et concis dans ses détails, on le trouve dans les livres ordinaires, expliqué dans un langage ordinaire,

\footnotetext{
87 «The Spanish code of commerce», The Law Magazine, 1832, vol. 7, p. 160.

88 «Mr. Bentham and Lord Brougham», The Law Magazine, 1832, vol. 7, p. 162.

89 «Third real property report», The Law Magazine, 1832-1833, vol. 8-9, p. 2.

90 «Criminal law of France», The Law Magazine, 1832-1833, vol. 8-9, p. 291.

91 «Third real property report», The Jurist, 1833, vol. 4, p. 98-99.

92 «Code des étrangers... par Légat», The Jurist, 1833, vol. 4, p. 153.

93 «Clear, just, and reasonable in its nature, plain and concise in its details, it is to be found in ordinary books, explained in ordinary language, intelligible to ordinary understandings. It is a law that he who runs may read, he who reads must comprehend, and he who comprehends, must approve, accordant as it is with humanity, religion and good sense» («The Spa-Fields verdict», The Law Magazine, 1833, vol. 10, p. 79).
} 
intelligible pour des intelligences ordinaires. C'est un droit que celui qui recherche peut lire, que celui qui lit doit comprendre et que celui qui comprend doit approuver, conformément à l'humanité, à la religion et au bon sens.»

Où l'on voit la double stratégie de la revue qui consiste à tenir la ligne de crête entre le respect aveugle des usages et la radicalité des réformes. Il convient d'argumenter pour établir la précellence du droit anglais, en utilisant les armes de ses détracteurs: ce droit est clair sur le fond, clair sur la forme - l'adjectif est utilisé deux fois -, il est accessible et compréhensible. En d'autres mots, il n'a aucun des défauts que lui prêtent Bentham, Humphreys et les autres codificateurs.

\section{CONCLUSIONS}

Les années 1825-1835 constituent ce que les Anglo-Américains appellent un momentum. De quoi s'agit-il? En matière diplomatique, militaire, commerciale, sportive ou idéologique, il existe des périodes propices (quelques dizaines de minutes lors d'un match ou d'une bataille, quelques semaines lors du lancement d'un nouveau produit, quelques années lors de l'émergence d'une idée) où certains acteurs prennent la main, mobilisent l'intérêt de tous et surmontent les obstacles de toutes sortes. Il ne reste à leurs adversaires qu'à se défendre du mieux possible en attendant un retournement de conjoncture. Les adversaires du common law ont ainsi réussi à créer un momentum où la réforme du système occupe l'espace public, où deux camps vont se faire face, où deux modèles vont s'opposer.

D'une part, les revues constituent l'un des théâtres d'opérations militaires privilégiés. Tout y contribue: l'enjeu de la querelle, la périodicité de la publication, l'anonymat des contributions, l'outil de la recension, l'habitude de l'affrontement entre avocats, la tendance progressive à la démesure. L'exemple des deux revues britanniques révèle notamment l'extrême tension des années 1827-1832. Si les promoteurs des codes n'avaient pas senti que le moment était enfin venu de passer des projets à leur réalisation, jamais ils n’auraient fondé The Jurist, ni à ce point comparé les deux systèmes au détriment systématique de l'equity, du statute et du common law. Si les défenseurs du common law n'avaient pas pris peur devant les progrès de l'idée codificatrice dans l'opinion publique, jamais ils n'auraient fondé The Law Magazine, jamais ils n'auraient sur-réagi comme ils l'ont fait contre Humphreys, Bentham et le modèle juridique français. Ensuite, on mesure à quel point le logos, l'ethos et le pathos sont liés dans la stratégie discursive des hommes. Chacun se jette dans la dispute en mobilisant tout ce qui lui semble apte à rassurer ses partisans, à écraser ses adversaires, à convaincre les hésitants. Mais, au fur et à mesure qu'avance la controverse, la somme de lectures devient telle qu'il faut tout maîtriser depuis le début pour savoir à quel auteur, à quelle formule, à quelle anecdote, le contradicteur fait allusion. Enfin - et c'est ici le point central -, une prise de distance permet de constater que l'hystérie collective, la violence des coups échangés et le durcissement des lignes éditoriales respectives ont créé un abîme entre les contradicteurs et, indirectement, entre les deux modèles juridiques. Chacun cherche, selon le mot de The Law Magazine à l'égard d'Humphreys, à anéantir («to finish») son adversaire. A la même époque, dans une revue littéraire nord-américaine comme The North American Review, la tonalité est plus apaisée, chacun obtient le droit de s'exprimer pour ou contre les deux systèmes, chacun réplique aux auteurs précédents sans les prendre à partie, la variété d’opinions est recherchée. 
Cependant, dans un cas comme dans l'autre, l'amplification de la lutte creuse irrémédiablement un fossé entre les contradicteurs que les positions médianes peinent à combler.

D’autre part, lorsqu'on rapproche ce théâtre d'opération des autres espaces de lutte (éditeurs, prises de parole publique, assemblées parlementaires), on prend la mesure de ce qu'a été la Codification Controversy du moment 1820-1835. Parce que la querelle a duré une dizaine d'années, parce que les échanges ont été violents, parce que le sujet a été le centre d'intérêt de tout ce que le Royaume-Uni et les Etats-Unis comptaient de juristes, parce qu'il a également mobilisé beaucoup de textes et de juristes européens, la controverse a contribué à attiser l'opposition entre les deux systèmes juridiques, en accentuant et en inversant les vices et les vertus respectifs. La controverse a constitué deux camps, le premier qui promeut le système codifié dans deux versions (radicale ou modérée) par opposition au common law, le second qui défend et systématise le common law, son génie propre et ses qualités par opposition aux mirages du droit codifié. En d'autres termes, cette controverse anglo-américaine a convaincu non seulement les juristes qui ont été engagés dans cette bataille, mais aussi leurs auditeurs et leurs lecteurs, qu'il existait bel et bien deux systèmes antagonistes. 